\title{
CRINOIDS FROM THE NADA MEMBER OF THE BORDEN FORMATION (LOWER MISSISSIPPIAN) IN EASTERN KENTUCKY
}

\author{
KEVIN G. LEE, ${ }^{1}$ WILLIAM I. AUSICH,${ }^{1}$ AND THOMAS W. KAMMER ${ }^{2}$ \\ ${ }^{1}$ Department of Geological Sciences, 155 South Oval Mall, The Ohio State University, Columbus 43210, <lee.2260@osu.edu $>$ and \\ < ausich.1@osu.edu>, 2Department of Geology and Geography, West Virginia University, Morgantown 26506-6300, <tkammer@wvu.edu>
}

\begin{abstract}
Thirty-four crinoid species, including four new species, are reported from the Nada Member of the Borden Formation in eastern Kentucky. The dominant crinoid group is monobathrids (18 species), but diplobathrids, disparids, cladids, and flexibles are also present. The four new species are the camerates Blairocrinus protuberatus, Uperocrinus acuminatus, and Aorocrinus nodulus, and the cladid Atelestocrinus kentuckyensis. The majority of the species in this fauna were previously known from what has traditionally been considered the "upper part" of the Burlington Limestone in the Mississippi River Valley and what is now recognized as the Burlington Pelmatozoan Assemblage III. The current study confirms the conclusion of Lane and DuBar (1983) that the Nada is middle Osagean in age, being deposited earlier than the well-documented Borden delta crinoid assemblages of north-central Kentucky and Indiana. The middle Osagean age of the fauna indicates a previously unrecognized unconformity between the Nada and the overlying Meramecianage Renfro Member of the Slade Formation. In addition, this is the first well-documented middle Osagean fauna from a siliciclastic facies in North America. The dominance by camerate crinoids is enigmatic, but may be related to either a low rate of sedimentation or greater larval dispersal abilities.
\end{abstract}

\section{INTRODUCTION}

D EPOSITION OF the Lower Mississippian Borden Delta is recorded by the Borden Formation in eastern Kentucky (Chaplin, 1980; Sable and Dever, 1990). It comprises, in ascending order, the Henley Bed, Farmers Member, Nancy Member, Cowbell Member, and Nada Member (Ettensohn et al., 1984). Crinoids are well known from the Borden sequence farther west, including the famous Crawfordsville and Indian Creek crinoid beds from central Indiana and the Button Mold Knob fauna from north-central Kentucky (Van Sant and Lane, 1964; Lane, 1973; Ausich and Lane, 1982; Kammer, 1984). Only a single low diversity fauna has previously been described from the Borden Formation of eastern Kentucky (Lane and DuBar, 1983). For this study, eight localities have been systematically collected for crinoid specimens (Appendix A). The crinoid fauna described by Lane and DuBar (1983), with 15 species, is primarily from one of these localities. These new collections indicate that Nada Member crinoid fauna includes more than 30 species, including the new species Blairocrinus protuberatus, Uperocrinus acuminatus, Aorocrinus nodulus, and Atelestocrinus kentuckyensis.

\section{LOCALITY AND STRATIGRAPHY}

The study area is in the vicinity of Morehead, Kentucky. The eight localities considered here are in Rowan, Bath, and Meniffee counties (Appendix A). This area lies along the western side of the Appalachian Basin and approximately $138 \mathrm{~km}$ east of the axis of the Cincinnati Arch.

The Nada Member is the uppermost member of the Borden Formation in eastern Kentucky. It is composed of gray, greenish shales interbedded with silty mudstones and siltstones. The Nada Member represents the marine part of the Borden Delta platform; nonmarine facies are absent (Chaplin, 1980).

The biostratigraphy of the Borden Formation in northeastern Kentucky has been studied using conodonts, ammonoids, and miospores. Miospore study (Richardson, 2003) correlates the Borden of eastern Kentucky to western European strata. Unfortunately, identifiable miospores have not been recovered from the Nada Member, but those from the underlying Cowbell Member are from the PC Biozone (Richardson, 2003). Thus, the Nada Member can be no older than Tn3b and is probably Tn3c (uppermost Tournaisian) in age, which is equivalent to the middle Osagean of the Mississippi River standard section. Similarly, the ammonoid and conodont assemblages reported in Work and Mason (2003) correlate with the "top of the Burlington Limestone" (p. 593). The conclusions of Lane and DuBar (1983) from their small Nada crinoid fauna also indicate a middle Osagean age, equivalent to the upper part of the Burlington Limestone of the Mississippian stratotype region. As discussed below, this study further verifies that assessment. However, as noted by Gahn and Kammer (2002) and Gahn (2002), widespread recognition in the crinoid literature of the lower and upper parts of the Burlington Limestone is problematic because the middle member of the Burlington Limestone, the Haight Creek Member, has been inconsistently cited through time as being either in the upper or the lower part of the Burlington Limestone (Gahn, 2002; Gahn and Kammer, 2002). Thus, previous literature is only reliable for the general correlation of these crinoids to parts of the Burlington Limestone, and these older literature citations are given as "lower" and "upper." This paper utilizes the revised biostratigraphy of Burlington crinoids given in Gahn (2002).

\section{FAUNAL ANALYSIS}

The Nada crinoid fauna consists of 34 species assigned to 27 genera, many of which were previously only known from the Burlington Limestone in Iowa, Illinois, and Missouri (Table 1). Species diversity and abundance are dominated by camerates (21 species), but disparids, cladids, and flexibles are also present. Most crinoid specimens are preserved in thin carbonate beds within the dominant gray, greenish shale of the Nada Member. The entire fauna is typically shallow-marine, composed of crinoids, brachiopods, corals, and bryozoans.

As discussed in Gahn and Kammer (2002) and Gahn (2002), the Burlington Limestone consists of three members: in ascending order the Dolbee Creek, Haight Creek, and Cedar Fork members. Through time, subdivision of these three members into a two-part Burlington ("upper" and "lower") has been inconsistent. Some authors have placed the Haight Creek Member into the "lower" Burlington, whereas others have placed it in the "upper." Gahn (2002) presented a new biostratigraphy of crinoids in the Burlington Limestone by recognizing three Burlington Pelmatozoan Assemblages (BPA) that roughly correspond to the three lithostratigraphic members of the Burlington. Further, Gahn (2002) summarized the distribution and relative abundance of all Burlington crinoids among these assemblages.

Review of the known Nada fauna with either the traditional or the Gahn (2002) biostratigraphy confirms the "upper" Burlington 


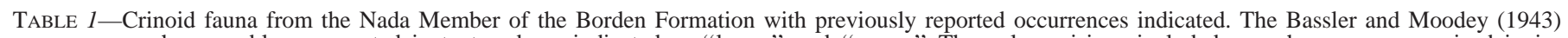
occurrences have problems as noted in text and are indicated as "lower" and "upper." The only revisions included are where now-recognized junior synonyms alter the Bassler and Moodey (1943) range. Gahn (2002) Burlington Pelmatozoan Associations have I as oldest and III as youngest. Number of known specimens is given in parentheses after species name. *designation for $R$. barrisi; " Upper" Burlington designation from Wachsmuth and Springer (1897).

\begin{tabular}{|c|c|c|}
\hline Taxa & $\begin{array}{c}\text { Bassler and Moodey (1943) } \\
\text { Reported Occurrences } \\
\text { (with revisions) }\end{array}$ & $\begin{array}{l}\text { Burlington Pelmatozoan } \\
\text { Associations } \\
\text { Gahn (2002) }\end{array}$ \\
\hline $\begin{array}{l}\text { Camerates } \\
\text { Family Rhodocrinitidae }\end{array}$ & & \\
\hline $\begin{array}{l}\text { Rhodocrinites barrisi divergens (3) } \\
\text { Gilbertsocrinus tuberculosus? (2) } \\
\text { Gilbertsocrinus typus? (1) }\end{array}$ & $\begin{array}{l}\text { "Upper" Burlington Limestone } \\
\text { "Upper" Burlington Limestone } \\
\text { Burlington Limestone and Montrose Chert Mbr, Keokuk Ls }\end{array}$ & $\begin{array}{l}\text { II* } \\
\text { II, III } \\
\text { I, II, III }\end{array}$ \\
\hline $\begin{array}{l}\text { Family Actinocrinitidae } \\
\text { Actinocrinites eximius (2) } \\
\text { Actinocrinites scitulus (4) } \\
\text { Blairocrinus protuberatus } \text { n. sp. (2) } \\
\text { Steganocrinus sp. (1) }\end{array}$ & $\begin{array}{l}\text { "Upper" Burlington Limestone } \\
\text { "Upper" Burlington Limestone }{ }^{1} \\
\text { [new species] } \\
\text { [not applicable] }\end{array}$ & $\begin{array}{l}\text { III } \\
\text { II, III } \\
\text { [new species] } \\
\text { [not applicable] }\end{array}$ \\
\hline $\begin{array}{l}\text { Family Batocrinidae } \\
\text { Uperocrinus pyriformis (12) } \\
\text { Uperocrinus acuminatus } \mathrm{n} . \mathrm{sp} .(8) \\
\text { Eretmocrinus cloelia }(6) \\
\text { Macrocrinus konincki (4) }\end{array}$ & $\begin{array}{l}\text { "Upper" Burlington Limestone and Chouteau Limestone } \\
\text { [new species] } \\
\text { "Upper" Burlington Limestone } \\
\text { "Upper" Burlington Limestone }\end{array}$ & $\begin{array}{l}\text { II, III } \\
\text { [new species] } \\
\text { I } \\
\text { II, III }\end{array}$ \\
\hline $\begin{array}{l}\text { Family Coelocrinidae } \\
\text { Dorycrinus quinquelobus (1) } \\
\text { Aorocrinus nodulus n. sp. (7) } \\
\text { Agaricocrinus planoconvexus (2) } \\
\text { Agaricocrinus inflatus? (1) }\end{array}$ & $\begin{array}{l}\text { "Upper" Burlington Limestone } \\
\text { [new species] } \\
\text { Burlington and Chouteau Limestone } \\
\text { "Upper" Burlington Limestone }\end{array}$ & $\begin{array}{l}\text { III } \\
\text { [new species] } \\
\text { I, II } \\
\text { II, III }\end{array}$ \\
\hline $\begin{array}{l}\text { Family Dichocrinidae } \\
\text { Dichocrinus pocillum? (1) } \\
\text { Dichocrinus sp. (1) } \\
\text { Paradichocrinus liratus (1) }\end{array}$ & $\begin{array}{l}\text { "Upper" Burlington Limestone } \\
\text { [not applicable] } \\
\text { "Upper" Burlington Limestone }\end{array}$ & $\begin{array}{l}\text { III } \\
\text { [not applicable] } \\
\text { III }\end{array}$ \\
\hline $\begin{array}{l}\text { Family Platycrinitidae } \\
\text { Platycrinites glyptus }(8) \\
\text { Platycrinites planus (2) } \\
\text { Platycrinities spinifer (1) }\end{array}$ & $\begin{array}{l}\text { "Upper" Burlington Limestone } \\
\text { "Upper" Burlington Limestone } \\
\text { "Lower" Burlington Limestone }\end{array}$ & $\begin{array}{l}\text { II, III } \\
\text { I, II } \\
\text { I }\end{array}$ \\
\hline $\begin{array}{l}\text { Cladids } \\
\text { Family Cyathocrinitidae } \\
\quad \text { Cyathocrinites iowensis (3) }\end{array}$ & Burlington Limestone to Warsaw Limestone & I, II, III \\
\hline $\begin{array}{l}\text { Family Botryocrinidae } \\
\text { Barycrinus spurius }(1) \\
\text { Costalocrinus cornutus (1) } \\
\text { Meniscocrinus } \text { sp. (1) } \\
\text { Pellecrinus obuncus }(1)\end{array}$ & $\begin{array}{l}\text { "Lower Burlington" to lower Warsaw Formation } \\
\text { "Lower" Burlington Limestone to Keokuk Limestone } \\
\text { [not applicable] } \\
\text { "Lower" Burlington Limestone }\end{array}$ & $\begin{array}{l}\text { I, II, III } \\
\text { I, II, III } \\
\text { [not applicable] } \\
\text { I }\end{array}$ \\
\hline $\begin{array}{l}\text { Family Mastigocrinidae } \\
\quad \text { Atelestocrinus kentuckyensis n. sp. (2) }\end{array}$ & [new species] & [new species] \\
\hline $\begin{array}{l}\text { Family Graphiocrinidae } \\
\text { Holcocrinus spinobrachiatus (1) }\end{array}$ & "Upper" Burlington Limestone & I, III \\
\hline $\begin{array}{l}\text { Family Scytalocrinidae } \\
\text { Blothrocrinus swallovi (1) }\end{array}$ & "Upper" Burlington Limestone & III \\
\hline $\begin{array}{l}\text { Family Coeliocrinidae } \\
\text { Coeliocrinus subspinosus }(1)\end{array}$ & “Upper” Burlington Limestone & III \\
\hline $\begin{array}{l}\text { Family Decadocrinidae } \\
\text { Decadocrinus scalaris (1) }\end{array}$ & "Upper” Burlington Limestone & II, III \\
\hline $\begin{array}{l}\text { Flexibles } \\
\text { Family Taxocrinidae } \\
\text { Taxocrinus spp. (4) }\end{array}$ & [not applicable] & [not applicable] \\
\hline $\begin{array}{l}\text { Disparids } \\
\text { Family Synbathocrinidae } \\
\quad \text { Synbathocrinus dentatus (6) }\end{array}$ & "Upper" Burlington Limestone & II, III \\
\hline $\begin{array}{l}\text { Family Calceocrinidae } \\
\text { Halysiocrinus dactylus (1) }\end{array}$ & "Upper" Burlington Limestone & I, II, III \\
\hline
\end{tabular}


age assignment for the Nada given in Lane and DuBar (1983) although assignment to a PBA is more equivocal. Twenty-two Nada crinoids are assigned to previously known species, and four are questionably assigned to previously known species (plus four are new and four are left in open nomenclature). Of these 26, 23 (92 percent) were reported from the "upper part" of the Burlington Limestone with 18 (72 percent) exclusively from the "upper part" (Bassler and Moodey, 1943). Using the BPA of Gahn (2002), correlation to the "upper part" is reduced. If both definitely and questionably assigned species are considered (26 total), 20 occur (six exclusively) in BPA III, 17 occur (one exclusively) in BPA II, and 11 occur (three exclusively) in BPA I. With only definitely assigned species, 17 occur (five exclusively) in BPA III, 15 occur (one exclusively) in BPA III, and 10 occur (three exclusively) in BPA I. The Nada fauna is clearly a mixture of taxa from throughout the Burlington Limestone. However, this study corroborates the conclusion of Lane and DuBar (1983) that the Nada fauna correlates with the "upper part" of the Burlington Limestone. Correlation with the BPA of Gahn (2002) is less clear. Nada crinoids are quite similar to both the BPA II and BPA III, but more occur exclusively in BPA III. However, it should be noted the Nada fauna contains Eretmocrinus cloelia Hall, 1861a; Platycrinites spinifer Wachsmuth and Springer, 1897; and Pellecrinus obuncus White, 1862 that are restricted to BPA I in the Burlington Limestone type area. Further, Rhodocrinites barrisi divergens Hall, 1861a; Platycrinites planus Owen and Shumard, 1850; and Agaricocrinus planoconvexus Hall, 1861b are restricted to BPA II in the Burlington Limestone type area.

Alternatively, if the dominant taxa for each BPA (Gahn, 2002) are considered, the Nada fauna is more similar to BPA II. However, taxa included in the diagnostic list are only monobathrid camerates, flexibles, and blastoids. The diagnostic associations are based on relative abundance; and because the sedimentary facies are so strikingly different between the Nada Member of the Borden Formation and the Burlington Limestone, relative abundance of species should be used with caution. In summary the Nada fauna is equivalent to the "upper part" of the Burlington Limestone and BPA III (perhaps PBA II also) of Gahn (2002). This middle Osagean age further demonstrates the progradational nature of the Borden clastic wedge (Ausich et al., 1979; Lane and DuBar, 1983; Richardson, 2003).

This crinoid fauna is unusual and quite significant paleoecologically, because it is a middle Osagean, camerate-dominated fauna in a siliciclastic facies. Thus, it provides insight into the transition of crinoid faunas from Osagean, camerate-dominated faunas of carbonate platforms to later faunas when cladids dominated in all facies (Lane, 1971). This transition is now recognized as a macroevolutionary break in Paleozoic crinoid faunas with the Middle Paleozoic Crinoid Macroevolutionary Fauna ranging from the Early Silurian through the Osagean and the Late Paleozoic Crinoid Macroevolutionary Fauna ranging from the Meramecian to the end of the Permian (Baumiller, 1994; Ausich et al., 1994). The reasons for this macroevolutionary change are not well understood, although the change may have been mediated by habitat reduction for camerates as carbonate platforms were reduced in area by clastic influx associated with late Paleozoic orogenies. The prototypical middle Osagean carbonate platform is the Burlington Limestone of the Mississippi River valley, considered a regional encrinite (Ausich, 1997).

The Burlington Limestone crinoid fauna consists of camerates, cladids, flexibles, and disparids (Bassler and Moodey, 1943), but in both species richness and abundance it is overwhelmingly dominated by camerates. This dominance was certainly enhanced by taphonomic factors (Meyer et al., 1990; Ausich and Sevastopulo, 1994), but it is very unlikely that this bias is great enough for the camerate dominance to be false. In fact, camerates dominated in carbonate settings from the Silurian to the late Osagean (Lane, 1971). Beginning during the late Osagean, more diverse facies were present across the midcontinent, and different major crinoid groups had preferences for different facies (Kammer and Ausich, 1987; Ausich et al., 1994; Kammer et al., 1997, 1998). Late Osagean carbonate facies included both carbonate platforms (Keokuk Limestone) and isolated carbonate buildups (Edwardsville Formation and Fort Payne Formation) (Lane, 1973; Ausich and Lane, 1980; Ausich and Meyer, 1990). These late Osagean carbonates all had camerate-dominated faunas. In contrast, siltstone and sandstone facies, such as Crawfordsville (Lane, 1973), were dominated by advanced cladid crinoids, and deeper-water shale facies had lower diversity faunas with primitive cladids and disparids dominating (Kammer, 1984). Even the older (latest Kinderhookian) deltaic crinoid fauna from the siltstones and shales of the Meadville Member of the Cuyahoga Formation in northern Ohio is dominated by cladids (52 percent of species) rather than camerates (30 percent) (Roeser, 1986).

The siliciclastic Nada Member is time-equivalent to the Burlington Limestone, but both are dominated (species richness and abundance) by monobathrid camerates (Table 1). Both faunas are dominated by actinocrinitids, batocrinids, coelocrinids, and platycrinitids, and they share many dominant genera, i.e., Uperocrinus Meek and Worthen, 1865, Eretmocrinus Lyon and Casseday, 1859, Aorocrinus Wachsmuth and Springer, 1897, and Platycrinites Miller, 1821, among others. Three of the five most abundant Nada species also occur in the "upper part" of the Burlington Limestone (Uperocrinus pyriformis Shumard, 1855, Eretmocrinus nodulus, Rowley, 1900, and Platycrinites glyptus Hall, 1861b), and the two remaining most common species are new taxa (Aorocrinus nodulus and Uperocrinus accuminatus). Three hypotheses are considered that may explain this anomalous occurrence of camerate crinoids. First, it may be that the environmental tolerance of camerate crinoids was much broader than previously understood, which would argue that the transition from the Middle Paleozoic to the Late Paleozoic Crinoid Macroevolutionary Fauna was not exclusively the result of a reduction in carbonate platforms (Lane, 1971; Ausich et al., 1994). However, it is unlikely that this one exception nullifies this evolutionary paleoecologic pattern based on numerous localities worldwide.

Second, the Nada Member probably does not record typical delta platform siliciclastic deposition. The Nada contains a high abundance of glauconite grains and numerous horizons with phosphate nodules, both of which suggest a very low rate of deposition, probably associated with a rise in sea level that reduced clastic input to the delta platform (Porrenga, 1967; Baturin, 1982; Harris and Whiting, 2000). Fossiliferous, thin marine shales, associated with biochemical precipitates such as glauconite and phosphorite, are common in transgressive systems tracts (Kidwell, 1989; Posamentier and Allen, 1999, p. 155). The Nada shales are finer-grained than the underlying siltstones of the Cowbell Member, which also supports the interpretation of a rising sea level reducing clastic influx, and this depositional model agrees with the sequence stratigraphic results Richardson (2003). Perhaps some of the Burlington Limestone camerate species had a wider tolerance to siliciclastics than others, and these species were able to inhabit the reduced sedimentation areas of the Nada delta platform. This exception to the known paleoecological trend may help to demonstrate the rule that camerates preferred lower rates of clastic sedimentation. This occurrence of camerates in the Nada also helps assessment of environmental tolerances for late Osagean descendants of Burlington crinoids.

Third, the dominance by camerates may indicate recruitment of those species with greater larval dispersal ability. Although beyond the scope of this study, it is possible that the overwhelming dominance by camerates in the Burlington Limestone may 
have led to dominance of their larva in the plankton and subsequent settling on the Nada sea floor.

\section{BIOSTRATIGRAPHIC SIGNIFICANCE}

The middle Osagean age of the Nada crinoids sheds light on the biostratigraphic relationships and depositional history of Mississippian rocks in northeastern Kentucky. The unit directly overlying the Nada is the Renfro Member of the Slade Formation, which appears to be conformable with the Nada (Ettensohn et al., 1984). The Renfro Member consists of dolostone and limestone and is relatively thin (0-6 m thick) in the study area (Chaplin, 1980, p. 26). Body fossils of corals, brachiopods, and crinoids are sparse, but endothyrid Foraminifera of Meramecian age have been reported (B. A. Skipp in Weir et al., 1971), as well as conodonts ranging in age from the Gnathodus texanus-Taphrognathus Zone to the Taphrognathus varians-Apatognathus Zone (J. W. Huddle in Sable and Dever, 1990, p. 44). These conodont zones extend from the late Osagean Keokuk Limestone to the late Meramecian lower St. Louis Limestone of the Mississippi Valley (Collinson et al., 1971). Although G. texanus begins in the Keokuk, it does range into the Meramecian Salem Limestone (Collinson et al., 1971; Lane and Brenckle, 2001). Chaplin (1980, p. 27) reports St. Louis age conodonts from near the top of the Renfro.

Comparisons of the stratigraphic ages of the Foraminifera and conodonts suggest that the Renfro Member is entirely Meramecian in age. The absence of any obvious late Osagean rocks and the apparent physical conformity indicate the Nada and Renfro are paraconformable. Late Osagean nonmarine environments that were undoubtedly present in eastern Kentucky, as the Borden Delta, prograded into western Kentucky and Indiana (Ausich et al., 1979; Sable and Dever, 1990; Khetani and Read, 2002), but these were not preserved in the rock record. The Renfro was most likely deposited as part of the transgressive-systems tract associated with the sea level rise that deposited the Warsaw-Salem limestone interval in western Kentucky (Khetani and Read, 2002). The dolomitic lithology and rare body fossils suggest an intertidal environment (Chaplin, 1980). The Renfro is overlain by the St. Louis Member of the Slade Formation (Ettensohn et al., 1984). The St. Louis also overlies the Warsaw-Salem interval of western Kentucky (Sable and Dever, 1990).

Thus, with data on the age of the Nada crinoids and the age of Renfro microfossils, a significant unconformity between the Borden and Slade Formations becomes apparent. There is no evidence for late Osagean rocks in eastern Kentucky.

\section{SYSTEMATIC PALEONTOLOGY}

Terminology follows Ubaghs (1978a), and supergeneric taxonomy follows Moore and Teichert (1978) with modifications by Ausich (1998). All specimens are housed in the Orton Geological Museum of The Ohio State University (OSU), the U.S. National Museum of Natural History (USNM), the Harvard Museum of Comparative Zoology (MCZ), or the University of Illinois (UI). Complete synonomies are only listed where revisions are made. Otherwise, the reader is given only the primary reference, a reference where the species is well illustrated, citation in Lane and DuBar (1983), and citation of the two comprehensive bibliographic indices: Bassler and Moodey (1943) and Webster (2003).

Class CRINOIDEA Miller, 1821

Subclass CAMERATA Wachsmuth and Springer, 1885

Order DiPLOBATHRIDA Moore and Laudon, 1943

Suborder EUDIPLOBATHRIDA Ubaghs, 1953

Superfamily RHODOCRINITOIDEA Roemer, 1855

Family RHODOCRINITIDAE Roemer, 1855

Genus RHODOCRINITES Miller, 1821

Type species.-Rhodocrinites versus Miller, 1821, by subsequent designation of Roemer (1855).

\section{RHODOCRINITES BARRISI DIVERGENS (Hall, 1861a)}

Rhodocrinus barrisi var. divergens HALL, 1861a, p. 324; WACHSMUTH AND SPRINGER, 1897, p. 230, pl. 12, figs. 3, 4a-4d, 5a, 5b.

Rhodocrinites barrisi divergens (HALL, 1861a). BASSLER AND MOODEY, 1943, p. 662; WeBSTER, 2003, p. 1598.

Diagnosis.-Calyx plate sculpturing (radials, basals, proximal interradials) central node from which radiating ridges project, connect to like ridges of adjoining plates; basal concavity deep; one to two fixed secundibrachials; eight to twelve total secundibrachials; 20 free arms; arms branch.

Material examined.-New specimens, OSU 50352 (locality 2) and OSU 51565 (locality 1).

Occurrence.-Bassler and Moodey (1943) reported R. barrisi divergens from the "upper part" of Burlington Limestone, Burlington and Pleasant Grove, Iowa, Gahn (2002) reported it from BPA II, and it is in the Nada Member of the Borden Formation.

Discussion.-The stellate calyx plate sculpturing and nodose tegmen plates of the Nada Rhodocrinites are diagnostic for $R$. barrisi divergens. The center of plates have spinelike processes or elongate nodes, connected by typically five-fold radiating, prominent ridges, which traverse the sutures and connect with the radiating ridges of the adjoining plates. The nodes on the basals are directed obliquely downward, whereas those on the radials and interradials point abaxially. This species was previously known only from the "upper part" of the Burlington Limestone at Burlington and Pleasant Grove, Iowa.

Wachsmuth and Springer (1897) placed this subspecies within Rhodocrinites barrisi (Hall, 1861a), while at the same time establishing a new subspecies, $R$. barrisi striatus. Subsequent bibliographers (Bassler and Moodey, 1943; Webster, 2003) have recognized these two subspecies, and this distinction is maintained here.

\section{Genus Gilbertsocrinus Phillips, 1836}

Type species.-Gilbertsocrinus calcaratus Phillips, 1836, by subsequent designation of Bassler (1938).

Discussion.-Two species of Gilbertsocrinus (one large with large plates and spinose/nodose basals; the other small with small plates and spinose basals) are part of the Nada fauna. Unfortunately, because these are incompletely preserved and because the current definition of species has a wide range of morphology, it is not possible to assign confidently either of these species. One of the smaller specimens (OSU 51566) has the proximal part of a tubular appendage preserved. This tubular appendage is composed of two plates, one on each side, which is present in middle Osagean and not in late Osagean species (Wachsmuth and Springer, 1897, p. 238).

\section{GILBERTSOCRINUS TUBERCULOSUS? (Hall, 1859)}

Trematocrinus tuberculosus HALL, 1859, p. 75.

Gilbertsocrinus tuberculosus (HALL, 1859). WACHSMUTH AND SPRINGER,

1897, p. 243, pl. 17, fig. 5a-5e; BASSLER AND MoOdeY, 1943, p. 488;

LANE AND DuBAR, 1983, p. 115-117, fig. 3k; Webster, 2003, p. 982.

Diagnosis._Gilbertsocrinus with medium to large individuals; calyx plates large, lacking pits at plate angles, no median ray ridge; basal plates with central spine or node, other calyx plates convex or nodose (rarely spinose); tubular appendages branch once; arms erect.

Material examined.-USNM 312168 and OSU 51566 from locality 1 .

Occurrence.-Bassler and Moodey (1943) reported G. tuberculosus from the "upper part" of the Burlington Limestone at Burlington, Iowa, and Pike County, Missouri, Gahn (2002) reported it from BPA II and BPA III, and it is in the Nada Member of the Borden Formation. 
Discussion.-This species has individuals in the medium to large size range, whereas the specimens from the Nada are small in size. Lane and DuBar (1983) identified the single specimen available to them as $G$. tuberculosus. Their identification was based on G. tuberculosus as having fewer fixed interradial plates. As they noted, this may be a variable character, but other characters certainly are variable also. We agree that this is the most probable assignment of this species; however, it should be questioned. Certainly, calyx plate size is different in adults of this species.

G. tuberculosus? is distinct from G. typus? (Hall, 1859), also from the Nada Member, because the G. tuberculosus? is small, has small plates, long spines as basal plates, and short spines or nodes on most other fixed calyx plates. In contrast, G. typus? is large, has large plates, nodes or short spines on basal plates, and other fixed calyx plates are only convex.

\section{GILBERTSOCRINUS TYPUS? (Hall, 1859)}

Trematocrinus typus HaLL, 1859, p. 73, unnumbered figure. Gilbertsocrinites typus (HALL, 1859). WACHSMUTH AND SPRINGER, 1897, p. 242 , pl. 14, figs. $1-3$; pl. 17, fig. 7a-7c; BASSLER AND MOODEY, 1943, p. 489; WEBSTER, 2003, p. 983.

Diagnosis.-Gilbertsocrinus with large individuals; calyx plates large, lacking pits at plate angles, no median ray ridge; basal plates with central node or small spines; other calyx plates typically convex but may be nodose or spinose, tubular appendages branch once, arms pendant.

Material examined.-OSU 51567 (locality 2).

Occurrence.-Bassler and Moodey (1943) reported G. typus from the Burlington Limestone at Burlington, Iowa, and from the Montrose Chert Member of the Keokuk Limestone at Pleasant Grove, Iowa, Gahn (2002) reported it in BPA I to BPA III, and it is in the Nada Member.

Discussion.-Although some specimens of G. typus have spines on calyx plates above the basals, most do not. This feature coupled with the fact that these plates are large and convex aligns it with G. typus. Gilbertsocrinus species from the Nada are compared above.

Order Monobathrida Moore and Laudon, 1943

Suborder COMPSOCRININA Ubaghs, 1978b

Superfamily PERIECHOCRINOIDEA Bronn, 1849

Family ACTINOCRINITIDAE Austin and Austin, 1842

Subfamily ACTINOCRININAE Austin and Austin, 1842 Genus ACTINOCRINITES Miller, 1821

Type species.-Actinocrinites triacontadactylus Miller, 1821, by subsequent designation of Wachsmuth and Springer, 1881.

\section{ACTINOCRINITES EXIMIUS (Kirk, 1943)}

Actinocrinus eximius KIRK, 1943, p. 264.

Actinocrinus griffithi WACHSMUTH AND SPRINGER, 1897, p. 568, pl. 52, fig. 7; BASSLER AND MOODEY, 1943, p. 270.

Actinocrinites griffithi (KIRK, 1943). WEBSTER, 2003, p. 309.

Diagnosis.-Calyx plates with small central node and one radiating ridge to all or some adjacent plates, radial plate higher than wide, first interradials approximately as high as wide, primibrachials highest fixed brachials in the vertical wall of calyx before distinct ray lobes, relatively few fixed tertibrachials, nodose or flat tegmen plates, and anal tube unknown.

Material examined.-OSU 50353 (locality 6) and OSU 51564 (locality 1 ).

Occurrence.-Bassler and Moodey (1943) recorded this species from the "upper part" of the Burlington Limestone in Iowa and Missouri, and it is in the Nada Member.

Discussion.-Two somewhat crushed calyxes of this species are available for study. The tall radial plates, relatively few plates in the vertical calyx walls, and calyx plate sculpturing make this a distinctive species. This is distinguished from A. scitulus (Meek and Worthen, 1860), which also occurs in the Nada, by calyx plate sculpturing, shape of radial plates, and plates in vertical calyx wall, and amount of ray lobation. The radial plate sculpturing distinguishes this species from other similar ones. Actinocrinites eximius has radial plate sculpturing with one ridge connecting to adjacent plates, whereas A. multiradiatus (Shumard, 1858) has more than one, and A. verrucosus (Hall, 1858) has very tumid radial plates with poorly defined or no ridges.

\section{ACTINOCRINITES SCITULUS (Meek and Worthen, 1860)}

Actinocrinus scitulus MeEK AND Worthen, 1860, p. 472; WachSMUth AND SPRINGER, 1897, p. 559, pl. 55, figs. 5, 6a, 6b.

Actinocrinites scitulus (MEEK AND WORTHEN, 1860). BASSLER AND MoOdey, 1943, p. 273-274; Webster, 2003, p. 318.

Diagnosis. - Calyx plates with large central node and plate convexity forming ridges to adjacent plates, radial plates approximately as wide as high, first interradials approximately as high as wide, secundibrachials highest fixed brachials in the vertical wall of the calyx before minor ray lobe, relatively few fixed tertibrachials, nodose or flat tegmen plates.

Material examined.-Two well-preserved specimens of A. scitulus are OSU 50370 (locality 1) and OSU 50394 (locality 1). Specimens questionably assigned to this species are OSU 50368 (locality 2) and OSU 51575 (locality 3).

Occurrence.-Bassler and Moodey (1943) reported this species from both the "lower" and "upper parts" of the Burlington Limestone at Burlington, Iowa, and Cedar Creek and Monmouth, Illinois. Gahn (2002) reported this species from BPA II and BPA III. In the Nada Member this species definitely occurs at locality 1 , and the questioned specimens are from localities 2 and 3.

Discussion.-Radial plates that are approximately equidimensional and calyx plate sculpturing with a node or convexity on the majority of a plate distinguish this species as noted in the discussion of $A$. eximius

Webster (2003) included A. scitulus as a junior synonym of $A$. sharonensis (Miller and Gurley, 1897). This is clearly an error as Miller and Gurley's (1897) younger name could not have priority over Meek and Worthen's (1860) older name, unless it was a replacement name for a homonym. There is no record in the literature that $A$. sharonensis was a replacement name for a homonym. Rather, the error can be traced to Brower (1965, p. 791), who recognized these two names as distinct species. Brower (1965) also included A. scitulus as a junior synonym of $A$. sharonensis in the synonymy list, perhaps because he wanted to cite Kirk (1943, p. 264), who thought these two species were synonyms.

$$
\text { Genus BlaIROCRINUS Miller, 1891a }
$$

Type species.-Blairocrinus trijugis S. A. Miller, 1891a, by monotypy.

\section{BLAIROCRINUS PROTUBERATUS new species} Figure 1.5-1.7

Blairocrinus sp. LANE AND DUBAR, 1983, p. 117, fig. 3a.

Diagnosis.-Elongate nodes on basal plates, radial plates, primanal, some first primibrachials, and other ray plates; first range of fixed interradials with low nodes, higher with only smooth sculpturing; lacking sculpture except for ray ridges; tegmen low, all plates either flat or with small node; narrow anal tube.

Description.-Calyx expanding distally with concave sides and with very low cone- shaped aboral cup; lacking sculpture except 

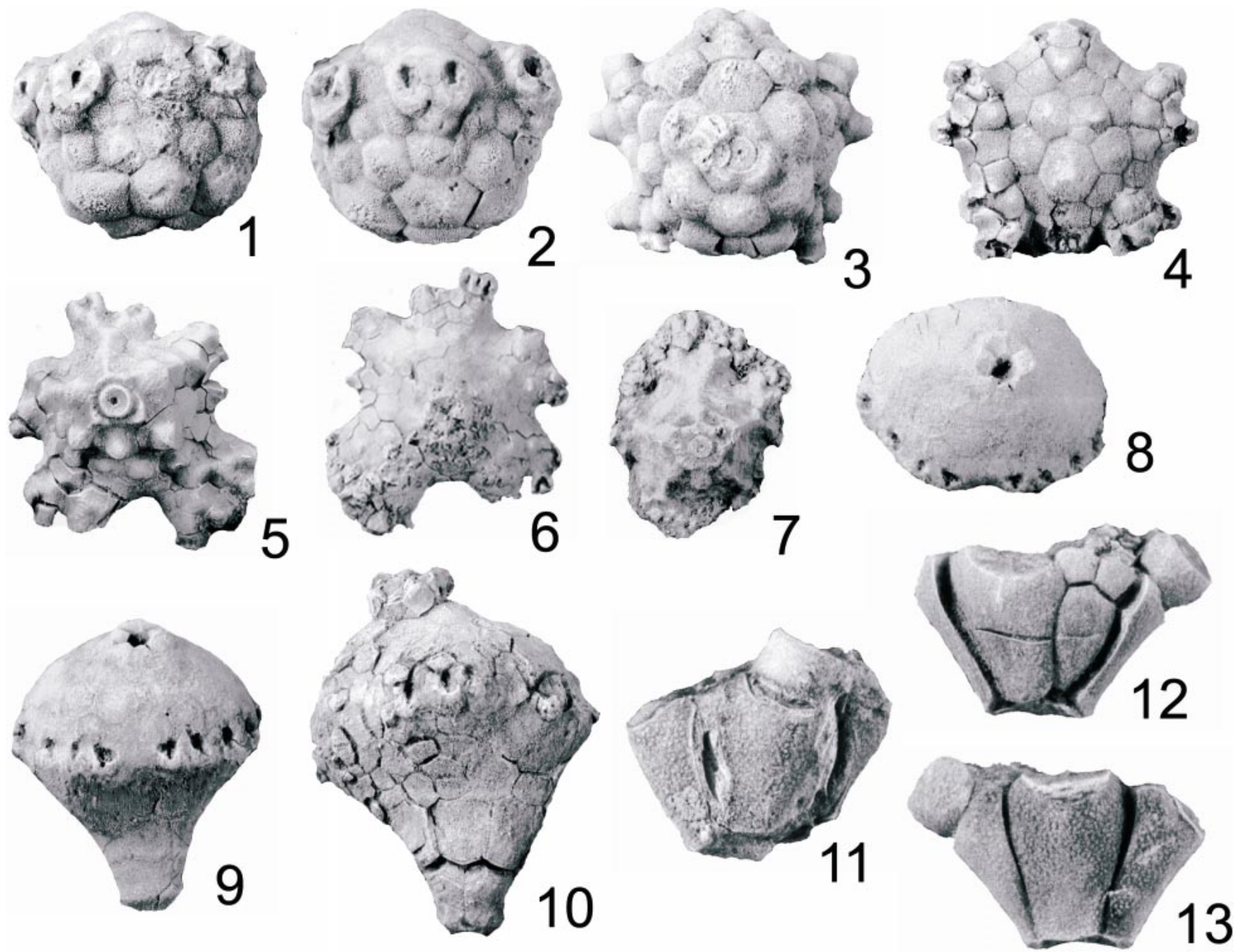

FIgURE 1-Nada Member crinoids. 1-4, Aorocrinus nodulus n. sp., ×3.0; holotype, 1, 2, OSU 50373, 1, CD-interray view; 2, A-ray lateral view; 3, 4, paratype, OSU 50376, 3, basal view; 4, oral view. 5-7, Blairocrinus protuberatus $\mathrm{n}$. sp.; $\times 2.0,5$, 6, holotype, OSU 50379, 5, basal view, 6, oral view; 7, paratype, USNM 312171, basal view. 8-10, Uperocrinus acuminatus $\mathrm{n}$. sp.; $\times 2.0$; 8, 9, holotype, OSU 50365, $\times 2.0,8$, oral view, 9, CD-interray view; 10, paratype, OSU 50366, $\times 2.0$, E-ray view. 11-13, Atelestocrinus kentuckyensis n. sp., $\times 2.5$; 11, paratype, OSU 50388, Aray lateral view, 12, 13, holotype, OSU 50389, 12, E-ray lateral view, 13, C-ray lateral view.

for ray ridges (Fig. 1.5, 1.7); tegmen flat or very low cone shaped; rays lobate, prominantly protuberant (Fig. 1.5), incorporating the second primibrachial and higher fixed brachials.

Basals three, small, barely visible from the side view, with large elongate node; basal circlet truncated proximally. Radials five, largest plates of the calyx, variable in size with large elongate node; hexagonal in shape, radial circlet interrupted by primanal.

Primanal hexagonal, same size and shape as radials, with large elongate node; second range with two plates with low nodes, different sizes; higher anals smooth and flat, variable in size and number; arrangement P-2-3-3; CD interray wider than normal interrays; anal plates in wide contact with tegmen.

Normal interrays much narrower than CD interray, in very narrow contact with tegmen, having three ranges of plates $(1-2-2,1-$ 2-1-1, or 1-2-3), first interradial hexagonal, much smaller than radials, variable in size and shape.

Fixed ray plates with prominent ray ridge; first primibrachial fixed, pentagonal or hexagonal, wider than high; second primibrachial axillary, hexagonal or heptagonal, approximately the same size as first primibrachial; first secundibrachial heptagonal in shape; second tertibrachial last fixed brachial; radial facets directed obliquely upward.

Tegmen flat or very low cone, proximal tegmen plates may have low spine, others flat with smooth sculpturing; anal tube slightly eccentric toward CD interray, narrow (Fig. 1.6), but other details unknown.

Twenty arm openings, but characters of free arms unknown.

Column unknown.

Etymology.-Latin protuberatus referring to the protuberant calyx rays.

Types.-Holotype OSU 50379 (locality 7); paratype USNM 312171 (locality 1).

Measurements.-OSU 50379: Calyx height, 9.1; aboral cup height, 7.2; maximum calyx width (A-CD), 13.4; basal plate height, 0.2; basal plate width, 2.7; radial plate height, 2.6; radial plate width, 2.8; primanal height, 2.2; primanal width, 2.8.

Occurrence.-Nada Member of the Borden Formation.

Discussion.-This new Nada species belongs in Blairocrinus, as recognized by Lane and DuBar (1983). Webster (2003) only recognized one species in Blairocrinus, but the placement of 
Blairocrinus arrosus Miller, 1892 by Brower (1967) is accepted here. Thus $B$. protuberatus is only the second species presently recognized in this genus. Blairocrinus protuberatus differs from $B$. trijugis and $B$. arrosus because it has only elongate nodes on basal plates, radial plates, primanal, and some first primibrachials, more distal ray plates have only a prominent median ray ridge; first range of fixed interradials with low nodes, higher with smooth sculpturing; the tegmen is high, all plates are flat with smooth sculpturing or with a small node; and the anal tube is narrow. In contrast, $B$. trijugis has stellate sculpturing on all calyx plates with prominent ray ridges, the tegmen is high with prominent spines on proximal tegmen plates, and the anal tube is wide; and Blairocrinus arrosus is distinct because it has elongate nodes on calyx plates; typically a poorly defined median ray ridge; all fixed interradials with nodes; the tegmen is high, all plates nodose; and the anal tube is wide.

Superfamily CARPOCRINOIDEA de Koninck and LeHon, 1854

Family BATOCRINIDAE Wachsmuth and Springer, 1881

Genus UPEROCRINUS Meek and Worthen, 1865

Type species.-Actinocrinus pyriformis Shumard, 1855, by original designation.

\section{UPEROCRINUS PYRIFORMIS (Shumard, 1855)}

Actinocrinus pyriformis SHUMARD, 1855, p. 192, pl. A, fig. 6a, 6b.

Lobocrinus pyriformis (SHUMARD, 1855). WACHSMUTH AND SPRINGER, 1897, p. 437, pl. 31, fig. 3a-3e.

Uperocrinus pyriformis (SHUMARD, 1855). BASSLER AND MOODEY, 1943, p. 721; LANe AND Dubar, 1983, p. 118, fig. 3o; Webster, 2003, p. 1808.

Diagnosis.-Calyx wider than high, large in size, sides concave; calyx plate sculpturing smooth; basal circlet high; regular interrays with four to six plates, not in contact with tegmen; tegmen high, plate sculpturing very convex to nodose; anal tube central; 20 arms.

Material examined.-OSU 50354 (locality 2), OSU 50355 (locality 5), OSU 50356 (locality 5), OSU 50357 (locality 1), OSU 50358 (locality 1), OSU 50359 (locality 2), OSU 50360 (locality 2), OSU 50361 (locality 1), OSU 51568 (locality 7), OSU 51569 (locality 7), OSU 51570 (locality 7), and USNM 312175 (locality $1)$.

Occurrence.-Bassler and Moodey (1943) reported U. pyriformis from the "upper part" of the Burlington Limestone in Iowa, Missouri, and Illinois, Gahn (2002) reported it from BPA II and III, and it is in the Nada Member of the Borden Formation.

Discussion.- Lane (1958) distinguished two groups within the genus Uperocrinus. The representatives of the first group have a gently convex calyx and tegmen. The second group consists of species with a calyx and tegmen that has distinctly concave sides. The specimens assigned to $U$. pyriformis undoubtedly belong to the second group. Uperocrinus pyriformis was initially described from the Burlington Limestone of Iowa, Missouri, and Illinois. It is a distinctive and common species in the "upper part" of the Burlington Limestone. Lane and DuBar (1983) described one specimen of this species from Morehead, Kentucky. They pointed out that unlike many other species of Uperocrinus, $U$. pyriformis may have the interradial areas of the calyx not in contact with tegmen plates. Eleven new specimens of $U$. pyriformis were recovered in this study, and this material confirms the Lane and DuBar (1983) identification.

\section{UPEROCRINUS ACUMINATUS new species} Figure 1.8-1.10

Eretmocrinus calyculoides (HALL, 1859). LANE AND DuBAR, 1983, p. 118 , fig. 3n.
TABLE 2-Measurements of Uperocrinus acuminatus n. sp. (in mm); holotype indicated by asterisk.

\begin{tabular}{lccccccc}
\hline \hline & $\begin{array}{c}\text { Calyx } \\
\text { Height }\end{array}$ & $\begin{array}{c}\text { Aboral } \\
\text { Cup } \\
\text { Height }\end{array}$ & $\begin{array}{c}\text { Calyx } \\
\text { Width } \\
\text { (A-CD) }\end{array}$ & $\begin{array}{c}\text { Basal } \\
\text { Plate } \\
\text { Height }\end{array}$ & $\begin{array}{c}\text { Basal } \\
\text { Plate } \\
\text { Width }\end{array}$ & $\begin{array}{c}\text { Radial } \\
\text { Plate } \\
\text { Height }\end{array}$ & $\begin{array}{c}\text { Radial } \\
\text { Plate } \\
\text { Width }\end{array}$ \\
\hline OSU 50362 & 23.2 & 15.6 & - & 4.0 & 3.8 & 5.1 & 4.1 \\
OSU 50363 & - & - & 17.8 & - & - & 3.9 & 2.5 \\
OSU 50364 & 21.3 & 16.7 & 14.5 & 3.6 & 3.4 & 4.1 & 3.2 \\
OSU 50365* & 19.2 & 14.2 & 12.4 & 3.2 & 2.8 & 3.9 & 3.1 \\
OSU 50366 & 23.5 & 17.2 & - & 4.5 & 3.8 & 4.6 & 3.1 \\
OSU 50367 & 26.7 & 20.1 & - & 4.1 & 3.8 & 5.7 & 3.9 \\
\hline
\end{tabular}

Diagnosis. - Calyx wider than high, medium in size, sides convex; calyx plate sculpturing smooth; basal circlet high; regular interrays in contact with tegmen; regular interrays with five to eight plates, in contact with tegmen; tegmen medium in height; plate sculpturing smooth to slightly convex; anal tube central; $17-$ 20 (typically 18) arms.

Description.-Calyx size small for genus, cone shape, sides concave, base truncated and tapers proximally (Fig. 1.9); arms grouped but not lobate; aboral cup plates smooth; plate sutures distinct.

Basals three, equal in size, as high as radials (Fig. 1.10); basal circlet conical, tapering proximally, 25-30 percent of height of calyx.

Radials five, hexagonal or heptagonal in shape, somewhat higher than basals; radial circlet approximately 30 percent of calyx height.

Primanal approximately same size as radials, interrupts radial circlet, second range in the posterior with three much smaller plates; posterior plating P-4-3-2-1 or P-3-4-2-2; posterior interray in contact with tegmen.

Normal interrays narrower than CD interray, first interradial hexagonal (rarely heptagonal); plating quite variable with second range typically with two plates but also one or three; plating 1$2-3-2-2,1-3-2-2,1-2-2-2,1-3,1-2-1$, or 1-1-1; may or may not be in contact with tegmen.

First primibrachial hexagonal, tetragonal, or hexagonal, wider than high; second primibrachial axillary, pentagonal or hexagonal, smaller than first primibrachial, wider than high; first and second secundibrachials approximately the same size as second primibrachials; first tertibrachials small, last fixed brachial either second secundibrachial or first tertibrachial; arm openings elliptical, higher than wide, directed obliquely upward.

Tegmen high, rounded, plates flat and smooth (Fig. 1.8); anal tube high and slender, central or subcentral toward the CD interray.

Arms 17-20; two to four arms in a ray. Free arms not known. Column unknown.

Etymology.-Latin acuminatus, referring to the tapering and pointed basal circlet.

Types.-OSU 50365 (locality 1) holotype; OSU 50362 (locality 5), OSU 50363 (locality 2), OSU 50364 (locality 1), OSU 50366 (locality 1), OSU 50367 (locality 2), OSU 51571 (locality 2), USNM 312172 (locality 1), and USNM 312173 (locality 1) paratypes.

\section{Measurements.-See Table 2.}

Occurrence.-Nada Member of the Borden Formation.

Discussion.-This new species differs from other species of Uperocrinus by having a relatively high and slender basal circlet that tapers proximally and by having flat and smooth calyx plates. Uperocrinus acuminatus is most similar to $U$. pyriformis that has robust and cylindrical basals, nodose tegmen plates, larger size, and regular interrays not in contact with the tegmen. It is similar to $U$. aequibrachiatus (McChesney, 1860) that also has smooth 
plates both on the tegmen and the calyx, but it differs from the new species by having lobate arm bases and nontapering, much lower basals. The new species is also similar to $U$. hageri (McChesney, 1860) in having tapering basals and smooth cup plates, but the latter has a lower and convex aboral cup and lower basals and radials.

Uperocrinus acuminatus has characteristics of both Uperocrinus groups, as defined by Lane (1958) and described above. It has a concave-sided aboral cup, a convex tegmen, and a high and tapering basal circlet. It is probably closer to the second subgroup, if the smaller size is ignored.

Lane and DuBar (1983) described two individuals (USNM 312172 and USNM 312173) from locality 1 that we assign to this new species. However, they designated them as Eretmocrinus calyculoides, which differs from the new species by having much lower and non-tapering basals, a much lower aboral cup, and the posterior interray not in contact with the tegmen. Five additional specimens have been collected during this investigation.

Genus ERETMOCRINUs Lyon and Casseday, 1859

Type species.-Eretmocrinus magnificus Lyon and Casseday, 1859; by monotypy.

\section{ERETMOCRINUS CLOELIA (Hall, 1861a)}

Actinocrinus cloelia Hall, 1861a, p. 266.

Eretmocrinus cloelia (HALL, 1861a). WACHSMUTH AND SPRINGER, 1897, p. 398, pl. 36, fig. 4a, 4b; Bassler and MoOdey, 1943, p. 456; WeBSTER, 2003, p. 888.

Diagnosis.-Calyx with height to width ratio of approximately 0.55 ; calyx sculpturing variable but dominated by prominent elongate nodes on basal plates, radial plates, primanal, and some ray plates; sculpturing of other calyx plates convex to circular node; basal circlet approximately 27 percent of calyx height; radial circlet approximately 27 percent of calyx height; radial plates approximately 1.3 times wider than high; regular interrays not in contact with tegmen, plating 1-2, 1-2-1; CD interray not in contact with tegmen, plating P-3-3; two secundibrachials; tegmen plates with circular spines anal tube unknown, free arms approximately twenty.

Material examined-COSU 50371 (locality 8), OSU 57572 (locality 2), OSU 57573 (locality 2), OSU 51574 (locality 2), and OSU 51576 (locality 3).

Occurrence.-Bassler and Moodey (1943) reported this species from the "upper part" of the Burlington Limestone at Burlington, Iowa, and Hannibal, Missouri; however, Gahn (2002) reported it from BPA I. It is now also from the Nada Member of the Borden Formation.

Genus MACROCRINUs Wachsmuth and Springer, 1897

Type species.-Actinocrinus konincki Shumard, 1855, by original designation.

\section{MACROCRINUS KONINCKI (Shumard, 1855)}

Actinocrinus konincki SHUMARD, 1855, p. 194, pl. A, fig. 8a-8c.

Macrocrinus konincki (ShUMARD, 1855). WACHSMUth AND SPRINGer, 1897, p. 447, pl. 35, figs. 1-3; BASSLER AND MoOdEY, 1943, p. 543; Lane And Dubar, 1983, p. 118, fig. 3c; Webster, 2003, p. 1174.

Diagnosis.-Macrocrinus with calyx as high as wide, sides straight; calyx sutures distinct, not beveled; basal circlet trilobed, extends proximally and outward; basal rim; radial plates with long, circular, or elongate spine; one to two fixed interradials in regular interrays; regular interrays not in contact with tegmen; three fixed plates above primanal; CD interray in contact with tegmen; anal tube central; 12 or 13 arms.
Material examined.-Lane and DuBar (1983) had USNM 312174 available (locality 1 ), and the new specimens are OSU 51540 (locality 1) and OSU 51577 (locality 2).

Occurrence.-Bassler and Moodey (1943) reported M. konincki from the "upper part" of the Burlington Limestone, Henderson County, Illinois; Burlington, South Augusta, and Honey Creek, Iowa; and Pike County, Missouri. Gahn (2002) reported this species from BPA II and III, and it is in the Nada Member.

Discussion.-Lane and DuBar (1983) identified Macrocrinus konincki in their collections, and additional specimens are now available. This is a small, spinose species of Macrocrinus, similar to $M$. gemmiformis (Hall, 1859). However, M. konincki is distinct with a calyx as wide as high, the trilobed basals extending proximally, and elongate or circular nodes on radial plates, whereas M. gemmiformis has a calyx wider than high, a truncate base, and circular nodes on radial plates.

Specimen OSU 51540 is a small specimen considered a juvenile of this species.

\section{Family COELOCRINIDAE Bather, 1899}

Genus AOROCRINUs Wachsmuth and Springer, 1897

Type species.-Dorycrinus immaturus Wachsmuth and Springer in Miller, 1889, by original designation.

\section{AOROCRINUS NODULUS new species Figure 1.1-1.4}

Aryballocrinus whitei LANE AND DuBAR, 1983, p. 117, fig. 3j, p.

Diagnosis.-Calyx low bowl, lobate at arm openings; calyx plates with very nodose sculpturing; three ranges of regular interrays; CD interray with three ranges of plates above the primanal; tegmen nearly flat; tegmen plates gently convex and smooth, except for very convex CD oral; two or three arms per ray.

Description.-Calyx low bowl-shaped; tegmen flat, lobate at arm openings; calyx plates convex with numerous fine ridges connecting to like ridges on adjacent plates.

Basals three, small, equal in size (Fig. 1.3), slightly visible in side view, proximally truncated. Radials five, much larger than basals, strongly convex, hexagonal or heptagonal, approximately as wide as high or slightly wider than high.

Primanal hexagonal, interrupts radial circlet (Fig. 1.1), slightly larger than the radials, second range with three plates; posterior interray plating P-3-5-2; anal opening in posterior interray at level of arm facets; posterior interray wider than normal interrays, in contact with tegmen.

Normal interrays in contact with tegmen; first interradial plate hexagonal, much smaller than radials, second range with two smaller plates that are in contact with two or three tegmen plates.

First primibrachials hexagonal, wider than high, second primibrachial much smaller, axillary; first secundibrachial small, last fixed brachial (Fig. 1.2); arm facets directed obliquely upward, horseshoe shaped.

Tegmen convex, composed primarily of orals; CD oral very large, strongly nodose, positioned eccentrically toward posterior (Fig. 1.4), surrounded by seven smaller oral plates in the CD interray (four orals and three additional tegmen plates).

Arms lobate, protruding for a short distance, 10 free arms, nature of free arms and column unknown.

Etymology.-Latin nodulus, referring to the conspicuously convex calyx plates.

Types.-OSU 50373 (locality 2) holotype; OSU 50372 (locality 2), OSU 50374 (locality 1), OSU 50375 (locality 5), OSU 50376 (locality 7), USNM 312169 (locality 1), and USNM 312170 (locality 1) paratypes.

Measurements.-See Table 3. 
TABLE 3-Measurements of Aorocrinus nodulus n. sp. (in mm); holotype indicated by asterisk.

\begin{tabular}{|c|c|c|c|c|c|c|c|c|c|}
\hline Specimen & $\begin{array}{l}\text { Calyx } \\
\text { Height }\end{array}$ & $\begin{array}{l}\text { Aboral } \\
\text { Cup } \\
\text { Height }\end{array}$ & $\begin{array}{c}\text { Calyx } \\
\text { Width } \\
\text { (A-CD) }\end{array}$ & $\begin{array}{l}\text { Basal } \\
\text { Plate } \\
\text { Height }\end{array}$ & $\begin{array}{l}\text { Basal } \\
\text { Plate } \\
\text { Width }\end{array}$ & $\begin{array}{l}\text { Radial } \\
\text { Plate } \\
\text { Height }\end{array}$ & $\begin{array}{l}\text { Radial } \\
\text { Plate } \\
\text { Width }\end{array}$ & $\begin{array}{l}\text { Primanal } \\
\text { Length }\end{array}$ & $\begin{array}{l}\text { Primanal } \\
\text { Width }\end{array}$ \\
\hline OSU 50372 & 7.2 & 5.6 & 9.7 & 0.3 & 2.1 & 2.0 & 2.8 & 1.9 & 2.1 \\
\hline OSU $50373^{*}$ & 7.9 & 6.5 & 11.4 & 0.6 & - & 2.1 & 2.6 & 2.1 & 2.5 \\
\hline OSU 50374 & 5.6 & 4.7 & 9.2 & - & - & 2.1 & 2.6 & 1.8 & 2.1 \\
\hline OSU 50376 & 9.8 & 6.7 & - & 0.5 & 3.1 & 2.9 & 3.6 & 2.5 & 2.4 \\
\hline
\end{tabular}

Occurrence.-Nada Member of the Borden Formation.

Discussion.-Aorocrinus nodulus differs from all other species of the genus by having very convex calyx plates and a very low bowl-shaped calyx. Aorocrinus symmetricus (Hall, 1858) has a very similar calyx morphology; however, it differs from the new species by having a more conical calyx, smooth calyx plates, more ranges (four to five) of anal plates above the primanal, and a slightly larger size. Another similar species, Dorycrinus unicornis (Owen and Shumard, 1850), also has nodose calyx plates and a relatively flat tegmen. It differs from the new species by having a robust spine on its $\mathrm{CD}$ oral plate and by having the first interradial large and followed by two very small and narrow plates. In contrast, in the new species the corresponding plates are all approximately the same size. Aorocrinus elegans, another similar species, differs from the new species by having a much higher, conical or subconical calyx.

Lane and DuBar (1983) described two poorly preserved individuals of this species collected from locality 1 and placed them in Aryballocrinus whitei. However, A. whitei differs from the new species by having a larger, higher calyx, less protuberant brachial lobes, and smooth, very thin calyx plates. This mistaken identification was due to the poor preservation of the two USNM specimens, which are totally crushed. Four new specimens provide the means by which to recognize this material as a new species of Aorocrinus.

\section{Genus DORYCRINUS Roemer, 1855}

Type species.-Dorycrinus mississippiensis Roemer, 1855, by monotypy.

\section{DORYCRINUS QUINQUELOBUS (Hall, 1859)}

Actinocrinus quinquelobus HALL, 1859, p. 15, unnum. text-fig.

Dorycrinus quinquelobus (HALL, 1859). WACHSMUTH AND SPRINGER, 1897, p. 460, pl. 42, figs. 7-9; BASSLER AND MOODEY, 1943, p. 440; LANE AND Dubar, 1983, p. 119, fig. 3i; WebSTER, 2003, p. 848.

Diagnosis.-Dorycrinus with calyx lobed at rays and interrays depressed; calyx plate sculpturing smooth, gently convex; basal circlet trilobed, extended proximally; basal concavity; first interradial as high as wide or higher than wide, sculpturing gently convex to convex, smooth; tegmen spines smooth.

Material examined.-In the Nada, D. quinquelobus is known from only USNM 312176 (locality 1).

Occurrence.-Bassler and Moodey (1943) reported D. quinquelobus from "upper part" of the Burlington Limestone, Burlington, Iowa, Gahn (2002) reported it from BPA III, and in the Nada Member of the Borden Formation.

Discussion.-Lane and DuBar (1983) identified and discussed this species based on a single crushed specimen. No additional specimens are available. This is in a group of Dorycrinus species from the "upper part" of the Burlington Limestone that are medium in size and have smooth, gently convex to convex calyx plates. Among these species, D. quinquelobus is distinguished by lacking median ray ridges and by having a trilobed basal circlet that extends proximally. D. quinquelobus is most closely associated with D. cornigerus (Hall, 1858) and D. inflatus Rowley and Hare, 1891.

\section{Genus AgARICOCRINus Hall, 1858}

Type species.-Agaricocrinus tuberosus Hall, 1858, by subsequent designation of Miller and Gurley (1897).

Discussion.-Species systematics of Burlington Limestone Agaricocrinus is much in need of revision. As demonstrated for Agaricocrinus from the Fort Payne Formation (Meyer and Ausich, 1997), a reexamination of prevailing species will probably result in the designation of several junior synonyms. A full revision of Osagean Agaricocrinus is far beyond the scope of this study. Species diagnostic characters used below are from Meyer and Ausich (1997) and modified to further distinguish taxa similar to Nada specimens (see Ehlers and Kesling, 1963).

\section{AgARICOCRINUS PLANOCONVEXUS Hall, 1861b}

Agaricocrinus planoconvexus HALL, 1861b, p. 3; WACHSMUTH AND SPRINGER, 1897, p. 503, pl. 38, fig. 6a-6c; BASSLER AND MoOdeY, 1943, p. 288; WEBSTER, 2003, p. 364.

Diagnosis.-Agaricocrinus with a pentalobate outline; calyx plates smooth; a height to width ratio of radial plate 1.0 or more; moderately deep basal concavity; first interradial plate relatively small; an anal region that does not protrude; wide, very convex to nodose second primibrachials; broad, laterally directed arm facets; tegmen low conical, smooth and small plates except for large, very convex to spinose $\mathrm{CD}$ oral plate.

Material examined.-OSU 50377 and OSU 51578 both from locality 2.

Occurrence.-Bassler and Moodey (1943) reported A. planoconvexus from the "lower" and "upper part" of the Burlington Limestone at Burlington, Iowa, and Louisiana, Missouri, and the Chouteau Limestone, Sedalia, Missouri. Gahn (2002) reported it from BPA I and II, and it is now from the Nada Member.

Discussion.-The low conical tegmen with a very prominent $\mathrm{CD}$ oral make this species a quite distinctive Agaricocrinus. It is most similar to A. stellatus (Hall, 1858) and A. bullatus Hall, 1858. These species differ because A. stellatus has granular calyx plate sculpturing, relatively small first interradials, equidimensional radial plates, a higher tegmen, flat tegmen plates, and laterally directed arm facets; A. bullatus has smooth calyx plate sculpturing, relatively large first interradials, radial plates wider than high, nodose tegmen plates, a low tegmen, and arm facets projecting somewhat distally; and A. planoconvexus has smooth calyx plate sculpturing, relatively small first interradials, radial plates as high as wide or higher, flat tegmen plates, a low tegmen, and laterally directed arm facets.

\section{AgARICOCRINUS INFLATUS? Hall, 1861b}

Agaricocrinus inflatus Hall, 1861b, p. 4; WachSMUth AND SPRINGer, 1897, p. 502, pl. 41, fig. 1a-1d; BASSLER AND MOODEY, 1943, p. 287; WEBSTER, 2003, p. 362. 
Diagnosis.-Agaricocrinus with a pentalobate outline; smooth calyx plates; shallow basal concavity; protruding anal region; wide second primibrachials; broad, laterally directed arm facets; tegmen very high, rounded; smooth and large tegmen plates.

Material examined.-OSU 50378 (locality 3).

Occurrence.-Bassler and Moodey (1943) reported A. inflatus from the "upper part" of the Burlington Limestone, Burlington, Iowa, Sagetown, Illinois, and Marion County, Missouri, Gahn (2002) reported it from BPA II and III, and it is in Nada Member of the Borden Formation.

Discussion.-A single crushed specimen is questionably assigned to Agaricocrinus inflatus. The tegmen is flattened obliquely, some tegmen plates are missing, and the remnants of an attached platyceratid are present. The large-plated tegmen that appears to have been very high and rounded align this specimen with A. inflatus. However, because the nature of this diagnostic feature is only inferred, the assignment is questioned.

Superfamily HeXACRINITOIDEA Wachsmuth and Springer, 1897 Family DiCHOCRINIDAE Miller, 1889

Subfamily DichOCRININAE Miller, 1889

Genus DichOCRINUs Münster, 1839

Type species.-Dichocrinus radiatus Münster, 1839, by monotypy.

\section{DiCHOCRINUS POCILLUM? Hall, 1861a}

Dichocrinus pocillum Hall, 1861a, p. 291; BASSLER AND MoOdey, 1943, p. 422; BROADHEAD, 1981, p. 122-123, pl. 7, figs. 4, 5, 7, 8, 10; Webster, 2003, p. 795.

Diagnosis.-Calyx equidimensional; calyx plates pitted; basal circlet low, bowl shaped; radial circlet vertical; 20 arms; tertibrachials biserial.

Material examined.-OSU 51543 from locality 7.

Occurrence.-Bassler and Moodey (1943) and Broadhead (1981) reported D. pocillum from the "upper part" of the Burlington Limestone at Burlington, Iowa, Gahn (2002) reported it from BPA III, and it is in the Nada Member of the Borden Formation.

Discussion.-A single, crushed calyx is questionably assigned to Dichocrinus pocillum. The calyx sculpturing and low bowlshaped basal circlet align this specimen to D. pocillum. The sculpturing on this species distinguishes it from Dichocrinus sp. discussed below.

\section{DICHOCRINUS sp.}

Material examined.-OSU 51579 from locality 7 in the Nada Member.

Discussion.-A single, poorly preserved radial circlet assigned to Dichocrinus was recovered. It is a smooth sculptured form. However, the radial facets are damaged, and the basal circlet and arms are unknown. The lineage of smooth-sculptured Dichocrinus ranges through the Mississippian and Pennsylvanian (Broadhead, 1981); however, the poor preservation of this specimen requires that its assignment be left in open nomenclature.

Genus PARADICHOCRINUs Springer, 1926

Type species.-Dichocrinus polydactylus Casseday and Lyon, 1862 , by original designation.

\section{PARADICHOCRINUS LIRATUS (Hall, 1861a)}

Dichocrinus liratus (HALl, 1861a). HALl, 1861a, p. 290; WACHSMUTH AND SPRINGER, 1897, p. 759; pl. 77, fig. 3a, 3b; pl. 76, fig. 8; BASSLER AND MoOdeY, 1943, p. 421.

Paradichocrinus liratus (HALL, 1861a). WeBSTER, 2003, p. 1332.
Diagnosis.-Sculpturing on basals coarse elongate nodes forming a proximal-distal ridge in interradial positions and striae or fine elongate nodes forming a ridge parallel to plate boundaries, radials with coarse elongate nodes aligned in rows radiating distally from radial facet and other irregular nodes; tegmen unknown.

Material examined.-OSU 50380 (locality 4).

Occurrence.-Bassler and Moodey (1943) and Broadhead (1981) reported $P$. liratus from the "upper part" of the Burlington Limestone at Burlington, Iowa, Gahn (2002) reported it from BPA III, and it is in the Nada Member of the Borden Formation.

Discussion.-Broadhead (1981) recognized three species on the basis of plate sculpturing and the relative size of ambulacrals and interambulacrals on the tegmen. Two species have coarse nodose sculpturing, P. liratus and $P$. polydactylus (Casseday and Lyon, 1862), with the latter sculpturing less coarse and more aligned in ridge patterns. The single aboral cup of this genus from the Nada Member is $P$. liratus. This specimen is crushed with part of the $\mathrm{D}$ radial and primanal not preserved and the arms and column not preserved.

Suborder GLYPTOCRININA Moore, 1952

Superfamily PlatyCRINITOIDEA Austin and Austin, 1842

Family PlatyCRINITIDAe Austin and Austin, 1842

Genus PlatyCRINITES Miller, 1821

Type species.-Platycrinites laevis Miller, 1821, by subsequent designation of Meek and Worthen (1865).

Discussion.-Ausich and Kammer (1990) and Ausich and Sevastopulo (2001) have recently considered species-level systematics of Lower Mississippian crinoid assemblages each with several species of Platycrinites. The species-diagnostic characters identified in those studies are applicable to the Nada Platycrinites. Species-level systematic revision within the Burlington Platycrinites is much needed; however, that is far beyond the scope of this study. Nada Platycrinites species are all well defined and are mostly comparable to those in the "upper part" of the Burlington Limestone.

\section{PlatyCRINITES GLYPTUS (Hall, 1861b)}

Platycrinus glyptus Hall, 1861b, p. 16; WACHSMUTH AND SPRINGER, 1897 , p. 693 , pl. 67 , figs. $4,5$.

Platycrinites glyptus (HALL, 1861b). BASSLER AND MoOdey, 1943, p. 620; Webster, 2003, p. 1447.

Platycrinites sp. LANE AND DuBAR, 1983, p. 120, fig. 3 b.

Diagnosis.-Large in size for genus; calyx plates thick, plate sculpturing composed of coarse, rugose ridges that mostly parallel plate boundaries, also on radials a few coarse ridges radiate from the radial facet; base of aboral cup rounded truncate; basal circlet high; radial circlet expands slightly distally; radial plate height greater than width; radial facet approximately 45 percent of distal radial width; radial facet inclination approximately 60 degrees; approximately 12 arms per ray; and biserial brachials develop distally.

Material examined.-OSU 50381 (locality 7), OSU 50382 (locality 2), OSU 51533 (locality 5), OSU 51534 (locality 2), OSU 51581 (locality 5), OSU 51582 (locality 2), OSU 51583 (locality 1), USNM 312179 (locality 1), and numerous isolated plates including USNM 312179 (locality 1).

Occurrence.-Bassler and Moodey (1943) reported Platycrinites glyptus from the "upper part" of the Burlington Limestone, Burlington, Iowa, and Henderson County, Illinois, Gahn (2002) reported it from BPA II and III, and it is in the Nada Member of the Borden Formation.

Discussion.-Platycrinites glyptus is the most common and widespread Platycrinites species in the Nada, and it is one of the 
most common of all Nada crinoid species. In addition to the specimens listed below, disarticulated basal circlets and radial plates are relatively common. Platycrinites glyptus belongs to the Platycrinities sculptus species group of Wachsmuth and Springer (1897), which includes P. sculptus (Hall, 1858), P. glyptus, P. saffordi Hall, 1858, P. scobina (Meek and Worthen, 1861), $P$. parvinodus (Hall, 1861b), and $P$. peculiaris (Wachsmuth and Springer, 1897). Among them, P. sculptus, P. glyptus, and $P$. saffordi are quite similar to one another. The current specimens differ from $P$. saffordi and $P$. sculptus by having a smaller size (although still higher than wide), much more equidimensional radial plates, a lower basal circlet, much coarser sculpturing, and fewer arms. This species was previously known from the "upper part" of the Burlington Limestone, Burlington, Iowa, and Henderson County, Illinois.

Three species of Platycrinites are recognized from the Nada Member. Platycrinites glyptus is large in size for the genus, calyx plates thick, has plate sculpturing of coarse ridges that mostly parallel plate boundaries, base of aboral cup rounded, high basal plate circlet, radial circlet expands slightly distally, radial plate higher than wide, radial facet approximately 45 percent of distal radial width, radial facet inclined at approximately 60 degrees, and typically 12 arms per ray. $P$. planus is large for the genus, calyx plates thin, plate sculpturing smooth, base of cup truncate cone, basal circlet high, radial circlet parallel-sided, radial plate higher than wide, radial facet approximately 60 percent of distal radial plate width, radial facet inclined approximately 50 degrees, and typically eight arms per ray. $P$. spinifer is small for the genus, has thin calyx plates, plate sculpturing of coarse circular to elongate nodes, base of aboral cup flat, basal circlet very low, radial circlet probably parallel-sided, radial plate wider than high, radial facet approximately 35 percent of distal radial width, radial facet inclination approximately 90 degrees, typically four arms per ray.

PlatyCRINITES PlANUS (Owen and Shumard, 1850)

Platycrinus planus Owen AND SHUMARD, 1850, p. 57, pl. 7, fig. 4a-4c; WachSMUth AND SPRINGER, 1897, p. 668, pl. 69, fig. 2a-2d.

Platycrinites planus (OwEN AND SHUMARD, 1850). BASSLER AND MOODEY, 1943, p. 625; LANE AND DUBAR, 1983, p. 119, fig. 3m; WEBSTER, 2003, p. 1457.

Diagnosis. - Large size for genus, calyx plates thin, plate sculpturing smooth, base of cup truncate conical, basal circlet high, radial circlet parallel-sided, radial plate height greater than width, radial facet approximately 60 percent of distal radial width, radial facet inclination approximately 50 degrees, eight arms per ray, biserial brachials develop distally.

Material examined.-One slightly crushed new specimen (OSU 50383 , locality 1) from the Nada Member, and the poorly preserved USNM 312178 (locality 1) is reassigned here from Platycrinites? incomptus (White, 1863).

Occurrence.-Bassler and Moodey (1943) reported P. planus throughout the Burlington Limestone, Burlington, Iowa, and Louisiana, Missouri, but Gahn (2002) reported it from only BPA I and II. It is also in the Nada Member of the Borden Formation.

Discussion.-This species belongs to the Platycrinites planus group of Wachsmuth and Springer (1897) that is characterized by flat and smooth plates without any sculpturing. It differs from other species of the group by having a very high basal circlet, very indistinct sutures, thin cup plates and slender arms. Although $P$. planus has been described from various horizons and locations of Lower Mississippian rocks, Ausich and Kammer (1990) revised the definition of this species and concluded that it only occurs in middle Osagean strata. See discussion of $P$. glyptus for comparison of this species to other Platycrinites in the Nada fauna.
PLATYCRINITES SPINIFER Wachsmuth and Springer, 1897

Playcrinus spinifer WACHSMUTH AND SPRINGER, 1897, p. 708, pl. 66, fig. 7.

Platycrinites spinifer (WACHSMUTH AND SPRINGER, 1897). BASSLER AND Moodey, 1943, p. 627; Webster, 2003, p. 1462.

Platycrinites tenuibrachiatus MEEK AND WORTHEN, 1869; LANE AND DuBAr, 1983, p. 119, fig. 3e.

Diagnosis. - Small size for genus, calyx plates thin, plate sculpturing composed of elongate or circular nodes that radiate down from radial facets; base of aboral cup flat; basal circlet very low; radial circlet probably parallel sided; radial plate wider than high; radial facet approximately 35 percent of distal radial width; radial facet inclination approximately 90 degrees; typically four arms per ray; and biseral brachials develop distally.

Material examined.-USNM 312177 (locality 1).

Occurrence.-Bassler and Moodey (1943) reported this species from the "lower part" of the Burlington Limestone, Gahn (2002) reported it from BPA I, and it is in the Nada Member of the Borden Formation.

Discussion.-We reassign Platycrinites tenuibrachiatus from Lane and DuBar (1983) to P. spinifer, because this specimen has the coarse circular to elongate nodes characteristic of this species. It is most similar to $P$. yandelli Owen and Shumard, 1850, but it has somewhat higher radial plates and more rows of nodes. $P$. spinifer is compared to other Nada Platycrinites in the discussion of $P$. glyptus above.

\section{CAMERATA incertae sedis}

Material examined.-OSU 51541 from Locality 1.

Discussion.- One isolated uniserial arm trunk with biserial ramules was recovered from the Nada. Three Osagean genera have similar arm trunks, including Cytidocrinus Kirk, 1944, Eucladocrinus Meek, 1872, and Steganocrinus Meek and Worthern, 1866. In the absence of calyx material to corroborate an identification, it is best to assign this specimen to Camerata incertae sedis.

Subclass Cladida Moore and Laudon, 1943 Suborder CYATHOCRININA Bather, 1899

Superfamily CYATHOCRINITOIDEA Bassler, 1938

Family CYATHOCRINITIDAE Bassler, 1938 Genus CyathocRINITES Miller, 1821

Type species.-Cyathocrinites planus Miller, 1821, by subsequent designation of Wachsmuth and Springer (1880).

Cyathocrinites IOWEnsis (Owen and Shumard, 1850)

Cyathocrinus iowensis OwEN AND SHUMARD, 1850, p. 63, pl. 7, fig. 11a$11 \mathrm{c}$.

Cyathocrinites iowensis (OWEN AND SHUMARD, 1850). BASSLER AND Moodey, 1943, p. 392; KAMMER AND Ausich, 1996, p. 852-857, figs. 7, 8; WeBSTER, 2003, p. 710.

Diagnosis.-Aboral cup height low to medium, does not lean posteriorly; aboral cup plates thin to medium thick, smooth sculpturing; basal plates swollen or tumid; radial plates lack shoulders; radial facts small, horseshoe shaped (crescentic in juveniles).

Material examined.-Specimens include OSU 50387 (locality 2), OSU 51532 (locality 7), and OSU 51586 (locality 2).

Occurrence-Cyathocrinites iowensis is the longest ranging species of Mississippian Cyathocrinites, extending from the "lower part" of the Burlington Limestone to the Somerset Shale Member of the Salem Formation. See Kammer and Ausich (1996, p. 857) for a complete locality listing. Gahn (2002) reported this species from BPA I to BPA III in the Burlington Limestone, and it is also in the Nada Member of the Borden Formation.

Discussion.-In the revision of Cyathocrinites iowensis by Kammer and Ausich (1996), this crinoid was recognized as a 
long-ranging species that now includes many junior synonyms. The Nada specimens are assigned to $C$. iowensis because of their smooth plates and swollen basals. Cyathocrinites gilesi (Wachsmuth and Springer, 1878) is similar to $C$. iowensis; however, the former has thicker cup plates, a slight posterior lean, larger arm facets (larger than half of the width of the radials), and much more robust arms. Cyathocrinites gilesi is known only from the upper part of the Burlington Limestone (Kammer and Gahn, 2003).

\section{Family BOTRYOCRINIDAE Wachsmuth and Springer, 1886} Genus BARYCRINUS Meek and Worthen, 1868

Type species.-Cyathocrinus spurius Hall, 1858, by original designation.

\section{BARYCRINUS SPURIUS (Hall, 1858)}

Cyathocrinus spurius Hall, 1858, p. 625, pl. 18, figs. 7, 8.

Barycrinus spurius (HALL, 1858). BASSLER AND MOODEY, 1943, p. 319; WEBSTER, 2003, p. 474.

Barycrinus sp. 1 LANE AND DUBAR, 1983, p. 121, fig. 31.

Diagnosis.-Aboral cup medium height, typically lower than other species of Barycrinus; cup plates smooth, slightly tumid.

Material examined.-USNM 312181 (locality 1).

Occurrence.-Bassler and Moodey (1943) reported Barycrinus spurius from the "lower" and "upper parts" of the Burlington Limestone and from the Montrose Chert Member of the Keokuk Limestone, Burlington, Iowa (Gahn and Kammer, 2002, p. 125). Gahn (2002) reported it from BPA I to BPA III in the Burlington Limestone. It also ranges from the upper part of the Keokuk Limestone to the Harrodsburg Limestone (Kammer and Ausich, 1996, p. 840). It is in the Nada Member of the Borden Formation.

Discussion. - Lane and Dubar (1983) listed the only known specimen as Barycrinus specimen 1. They compared this specimen to B. wachsmuthi (Meek and Worthen, 1861) which also has smooth cup plates, but noted the latter has a higher cup. Barycrinus wachsmuthi is considered to be a junior synonym of $B$. rhombiferus (Owen and Shumard, 1852) (Kammer and Ausich, 1996, p. 841). The only known specimen from the Nada compares closely with specimens of B. spurius (e.g., Kammer and Ausich, 1996, fig. 1.1-1.3), a species originally described from the Keokuk Limestone. Gahn and Kammer (2002, p. 125) identified isolated cups of $B$. spurius from both the lower and upper parts of the Burlington Limestone.

\section{Genus Costalocrinus Jaekel, 1918}

Type species.-Poteriocrinus dilatatus Schultze, 1867, by original designation.

\section{COSTALOCRINUS CORNUTUS (Owen and Shumard, 1850)}

Cyathocrinus cornutus OwEN AND SHUMARD, 1850, p. 63, pl. 7, fig. 8a, $8 \mathrm{~b}$.

Barycrinus cornutus (OwEN AND SHUMARD, 1850). BASSLER AND MoOdey, 1943, p. 317.

Costalocrinus cornutus (OwEn AND SHUMARD, 1850). KAMMER AND

Ausich, 1996, p. 852, fig. 6.14-6.16; WeBster, 2003, p. 634.

Barycrinus sp. 2 LANE AND DUBAR, 1983, p. 121, fig. 3d.

Diagnosis.-Cup similar to Barycrinus except that anal $\mathrm{X}$ is enlarged and supports a posterior interray basin; basal and radial plates exhibit large and irregularly shaped nodes.

Material examined.-USNM 312182 (locality 1).

Occurrence.- "Lower and upper parts" of the Burlington Limestone, Burlington, Iowa; Lake Valley Formation, Lake Valley, New Mexico; New Providence Shale of Kentucky and Indiana; and the Fort Payne Formation, Whites Creek Springs, Tennessee (Kammer and Ausich, 1996, p. 852; Gahn and Kammer,
2002, table 1). Gahn (2002) reported it from the Burlington Limestone in BPA I to BPA III, and it is in the Nada Member of the Borden Formation.

Discussion.- Lane and Dubar (1983) noted that the Nada specimen closely resembled Barycrinus cornutus, yet did not assign it to this species. McIntosh (1984) assigned this species to Costalocrinus because of the enlarged anal $\mathrm{X}$ plate that supports a posterior interray basin. The Nada specimen is incomplete and does not show evidence of the posterior interray basin, but the large and irregular nodes on the basals and radials leaves no doubt of its assignment to $C$. cornutus. Of the six known species of Costalocrinus, only $C$. cornutus occurs in the Mississippian; the remainder are restricted to the Devonian (Kammer, 2001).

Genus Meniscocrinus Kammer and Ausich, 1996

Type species.-Meniscocrinus magnitubus Kammer and $\mathrm{Au}-$ sich, 1996, by original designation.

\section{Meniscocrinus sp. Figure 2.1, 2.2}

Barycrinus sp. 3 LANE AND DuBAR, 1983, p. 121, fig. 3g.

Diagnosis.-Aboral cup low; cup plates swollen to nodose; radial facets angustary, crescentic; prominent posterior interrary basin composed of multiple anal plates; second primibrachial axillary.

Material examined.-USNM 312183 (locality 1).

Occurrence.-Nada Member, Borden Formation.

Discussion.-Meniscocrinus was previously known from only three specimens from the late Osagean Edwardsville Formation at Indian Creek, Indiana (Kammer and Ausich, 1996, p. 861). The occurrence in the Nada extends the range of this rare genus. A cladistic analysis indicated that Meniscocrinus is more closely related to Costalocrinus than to Barycrinus (Gahn and Kammer, 2002, fig. 2). In fact, the closest taxon is $C$. cornutus.

The Nada specimen clearly shows the outline of the prominent posterior basin, which was composed of several anal plates (Fig. 2.1, 2.2); however, one or more plates are missing so the exact structure of the posterior basin cannot be resolved. Thus, it seems best to leave this species in open nomenclature rather than assign it to either M. magnitubus or a new species. The Nada specimen is also much smaller than specimens of M. magnitubus, which may suggest it is a new species, or simply a juvenile.

\section{Genus Pellecrinus Kirk, 1929}

Type species.-Cyathocrinus hexadactylus Lyon and Casseday, 1859 , by monotypy.

\section{Pellecrinus obuncus (White, 1862)}

Figure 2.3-2.5

Poteriocrinus obuncus WHITE, 1862, p. 11.

Poteriocrinites obuncus (WhITE, 1862). BASSLER AND MoOdeY, 1943, p. 643; WEBSTER, 2003, p. 1520.

Diagnosis. - Cup plates smooth, ranging from thin at the edges to thick in the center; radial facets angustary, crescentic, with distinct fulcral ridge extending the width of the facet; two or three anal plates in the cup.

Material examined.-OSU 51537 (locality 2) in the Nada Member. The holotype is MCZ 104512, from the lower part of the Burlington Limestone, Burlington, Iowa.

Occurrence.-This species was previously known only from the "lower part" of the Burlington Limestone, Gahn (2002) reported it from BPA I, and it is in the Nada Member, Borden Formation.

Discussion.-Kammer and Gahn (2003, p. 131) first reported 
this genus from the lower part of the Burlington Limestone as Pellecrinus sp., which consisted of three specimens, and extended the range of this genus downward into the middle Osagean. Subsequently Kammer, while studying Burlington Limestone advanced cladids, discovered that Poteriocrinites obuncus was not an advanced cladid but rather a Pellecrinus. The holotype specimen of this species is herein illustrated for the first time (Fig. 2.4, 2.5) and is judged to be conspecific with the Nada specimen (Fig. 2.3), which is an isolated radial plate, as well as Pellecrinus sp. in Kammer and Gahn (2003).

Suborder DENDROCRININA Bather, 1899

Superfamily MASTIGOCRINOIDEA Jaekel, 1918

Family MASTIGOCRINIDAE Jaekel, 1918

Genus AtelestocRINUs Wachsmuth and Springer, 1886

Type species.-Atelestocrinus delicatus Wachsmuth and Springer, 1886, by subsequent designation of Miller (1889).

\section{ATELESTOCRINUS KENTUCKYENSIS new species} Figure 1.11-1.13

Diagnosis. - Radials much higher than wide; two small, polygonal tegmen plates incorporated into the cup at A ray; A-ray radial teardrop-shaped, much smaller than other radials.

Description.-Aboral cup medium size, high, expands distally; aboral cup plates smooth or with broad pustules (Fig. 1.11). Infrabasal and basal plates unknown. Five radial plates, trapezoidal (wider distally), approximately twice as wide as high; A radial much smaller than other radials, teardrop-shaped, radial facet absent, two small tegmen plates incorporated into aboral cup above A radial (Fig. 1.12); radial facets peneplenary, declivate (Fig. 1.3). First primibrachial on E ray rectangular uniserial (Fig. 1.11), wider than high; remainder of arms and column unknown.

Etymology. - From the state of Kentucky.

Types.-Holotype OSU 50388 from locality 5, with a complete radial circlet preserved. Paratype OSU 50389 from locality 1.

Measurements.-Holotype, OSU 50388, radial plate height, 8.2; radial plate width, 4.7; primibrachial height, 2.0; primibrachial width, 3.5; paratype, OSU 50389, radial plate height, 8.9; radial plate width, 5.6; A radial plate height, 5.5; A radial plate width, 2.9, primibrachial height, 2.6; primibrachial width, 3.0.

Occurrence.-Nada Member of the Borden Formation.

Discussion.-This new species is known from only the radial circlet. This has four arm-bearing radials and one radial without a radial facet; hence, it is assigned to Atelestocrinus, which is a rare Mississippian genus known previously from only three species and relatively few specimens. The new species differs from A. robustus Wachsmuth and Springer, 1885 and A. delicatus by having radials that are much higher than wide and by the absence of any anal plates. The only other species within the genus, $A$. indianensis Ausich and Lane, 1982, is from the Edwardsville Formation of the Borden Group in Indiana, and it is very similar to the new species in terms of the shape of the radials and the absence of anal plates. However, it differs from the new species by having an A radial without the teardrop shape, and it does not have the two tegmen plates lying above the A radial in the aboral cup. Moreover, the new species is larger than A. indianensis, and it is possible that it is the ancestor of $A$. indianensis and changed by elimination of the two A-ray tegmen plates from the cup.

Suborder POTERIOCRININA Jaekel, 1918

Superfamily ERISOCRINOIDEA Wachsmuth and Springer, 1886

Family GRAPHIOCRINIDAE Wachsmuth and Springer, 1886 Genus HolCOCRINUs Kirk, 1945

Type species.-Graphiocrinus longicirrifer Wachsmuth and Springer, 1890 , by original designation.
HOLCOCRINUS SPINOBRACHIATUS (Hall, 1861a) Figure 2.6-2.9

Graphiocrinus spinobrachiatus HALL, 1861a, p. 306; BASSLER AND Moodey, 1943, p. 497.

Holcocrinus spinobrachiatus (HALL, 1861a). WebSTER, 2003, p. 1072.

Diagnosis.-Arms slender, with nodes on each brachial; primibrachial one axillary, higher than wide; one anal plate in cup.

Description.-Calyx medium-sized; aboral cup bowl-shaped, plates convex or flat; infrabasals not visible in side view; basals medium-sized, approximately 30 percent of cup height, wider than high, visible from the side; radials large, approximately 70 percent of the cup height, with articular facets full width of plates. Only one anal plate in the cup, equidimensional sitting directly above CD basal. One primibrachial in each ray, axillary, higher than wide, constricted at midlength. Arms 10, isotomous; brachials cuneate uniserial, slender, bearing one node or low spine in each (Fig. 2.9). Column pentagonal at proximal end; distal columnal and holdfast unknown.

Material examined-OSU 50390 (Fig. 2.9, locality 3) with arms attached and the CD interray exposed. The holotype, USNM S2860 (Fig. 2.6), and two nontypes, USNM S2861 (Fig. 2.7, 2.8) and USNM S2864.

Occurrence.-Bassler and Moodey (1943) reported H. spinobrachiatus from the "upper part" of the Burlington Limestone, Burlington, Iowa, Gahn (2002) reported it from BPA I and III, and it is in the Nada Member of the Borden Formation.

Discussion.-This species is distinct from other species of $\mathrm{Hol}$ cocrinus because of its higher primibrachials and nodose arm brachials. A very similar species is Holcocrinus nodobrachiatus (Hall, 1861a) from the late Osagean at Crawfordsville and Monroe Resevoir in Indiana (see Ausich and Lane, 1982), but it differs by having a circular columnal, more robust arm brachials, and radials with rows of nodes on the distal and proximal edges. Holcocrinus spinobrachiatus was previously known from the upper part of the Burlington Limestone, Burlington, and Weaver (Lee Co.), Iowa. Burlington Limestone specimens of $H$. spinobrachiatus are illustrated for the first time, herein (Fig. 2.6-2.8).

Superfamily SCYTALOCRINOIDEA Moore and Laudon, 1943

Family BlothrocRINIDAE Moore and Laudon, 1943 Genus BLOTHROCRINUS Kirk, 1940

Type species.-Poteriocrinus jesupi Whitfield, 1881, by original designation.

\section{BLOTHROCRINUS SWALLOVI (Meek and Worthen, 1860)} Figure 2.10, 2.11

Poteriocrinus swallovi MeEK AND Worthen, 1860, p. 394; MeEK AND Worthen, 1866, p. 183, pl. 16, fig. 4a, 4b.

Blothrocrinus swallovi (MEEK AND WORTHEN, 1860). BASSLER AND MoOdey, 1943, p. 335; Webster, 2003, p. 507.

Diagnosis.-Aboral cup conical, high, bowl shaped, medium to large size, plates smooth; basals five, higher than wide, pentagonal in shape; radials wider than high, arm facets crescentic, peneplenary; three anal plates in cup; arms relatively stout, with two primibrachials in the $\mathrm{C}, \mathrm{D}$, and $\mathrm{E}$ rays (the $\mathrm{A}$ and $\mathrm{B}$ rays lack preserved arms), first primibrachial much wider than high, second primibrachial pentagonal in shape; arm brachials cuneate uniserial with pinnules. Infrabasals, column, and anal sac not preserved on this specimen.

Material examined.-One partial, slightly crushed specimen OSU 50391 (locality 7).

Occurrence.-Blothrocrinus swallovi was listed in Bassler and Moodey (1943) from the "upper part" of the Burlington Limestone, Gahn (2002) reported it from BPA III, and it is in the Nada Member of the Borden Formation. 

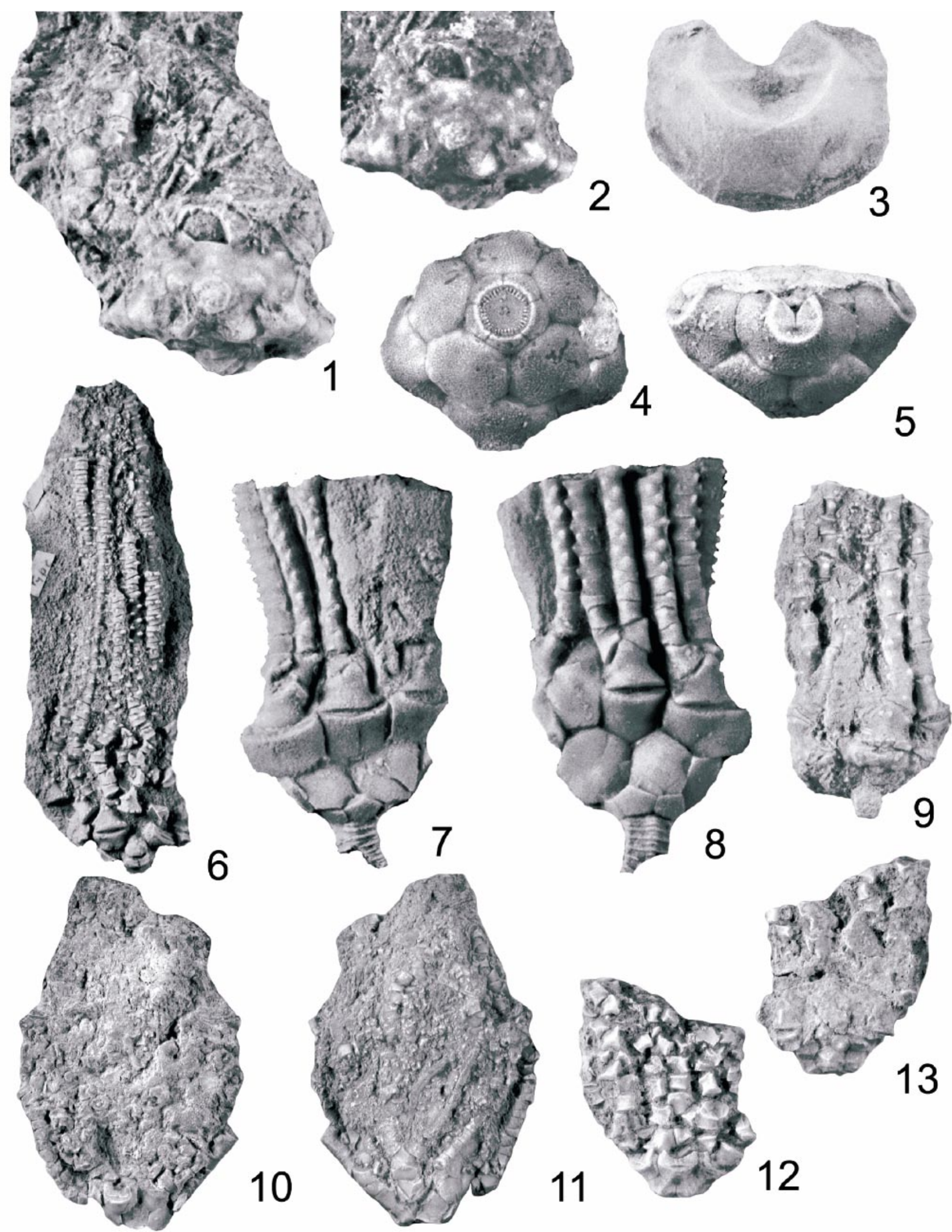
Discussion.-There are three species of Blothrocrinus reported from the Burlington Limestone: B. swallovi, B. cultidactylus (Hall, 1859), and $B$. jesupi. The exact relationships are unknown. The Nada specimen (Fig. 2.10, 2.11) is assigned to B. swallovi because it compares reasonably well with the holotype (UI X-33). The holotype of $B$. cultidactylus (UI X-802) lacks infrabasal and basal plates and has an A ray similar to the other rays, unlike $B$. swallovi and B. jesupi, which have 11-15 primibrachials in the A ray. Thus, B. cultidactylus may belong in a different genus, but further study is necessary. Blothrocrinus jesupi may be a gerontic $B$. swallovi, but this is currently unclear.

\section{Family CERCIDOCRINIDAE Moore and Laudon, 1943 Genus COELIOCRINUs White, 1863}

Type species.-Poteriocrinus dilatatus Hall, 1861a, by subsequent designation of Miller (1889).

\section{CoEliocrinus SUBSPINOSUS White, 1863}

Coeliocrinus subspinosus WhITE, 1863, p. 501; SPRINGER, 1926, p. 86, pl. 25, figs. 2, 3; BASSLER AND MOODEY, 1943, p. 369; Webster, 2003 , p. 619.

Diagnosis.-Coeliocrinus with cylindrical anal sac with large spines on the distal end; secundibrachials rectangular.

Material examined.-OSU 51535 (locality 7).

Occurrence.-Bassler and Moodey (1943) reported Coeliocrinus subspinosus from the "upper part" of the Burlington Limestone at Burlington, Iowa, Gahn (2002) reported it from BPA III, and it is in the Nada Member of the Borden Formation.

Discussion.-Four species of Coeliocrinus have been reported from the Burlington Limestone: $C$. dilatatus (Hall, 1861a) and $C$. ventricosus (Hall, 1861a) from the "lower part" of the Burlington, $C$. lyra from both the "upper and lower parts" of the Burlington, and $C$. subspinosus from the "upper part" of the Burlington. Both $C$. dilatatus and $C$. ventricosus have a large, inflated, heavy-plated anal sac unlike the Nada specimen. Coeliocrinus lyra does not exhibit an anal sac. Only C. subspinosus has large projecting spines at the distal end of the sac, as does the Nada specimen.

\section{Superfamily DECADOCRINOIDEA Bather, 1890} Family DECADOCRINIDAE Bather, 1890

Genus DECADOCRINUS Wachsmuth and Springer, 1880

Type species.-Poteriocrinites (Graphiocrinus Scaphocrinus) scalaris Meek and Worthen, 1870, by original designation.

\section{DECADOCRINUS SCALARIS (Meek and Worthen, 1870)} Figure 2.12, 2.13

Poteriocrinites (Graphiocrinus Scaphocrinus) scalaris MEEK AND WoRTHEN, 1870, p. 145.

Poteriocrinites (Scaphocrinus) scalaris MeEK AND Worthen, 1870. MEeK AND Worthen, 1873, pl. 2, fig. 10.

Decadocrinus scalaris (MEEK AND WORTHEN, 1870). BASSLER AND Moodey, 1943, p. 407; Webster, 2003, p. 756.

Diagnosis.-Basals bulbous; pits or depressions at cup plate corners; nine arms total; second primibrachial axillary, except for atomous A ray; brachials cuneate; column pentagonal.

Material examined.-OSU 51536 (locality 5).

Occurrence.-Bassler and Moodey (1943) reported Decadocrinus scalaris from the "upper part" of the Burlington Limestone, Gahn (2002) reported it from BPA II and III, it is in the Nada Member of the Borden Formation.

Discussion.-This taxon is represented by a single crown in which the arms are incomplete and largely disarticulated. It is consistent with the diagnosis of Decadocrinus by Kammer and Ausich (1993) in having three anal plates fixed in the aboral cup, bulbous basal plates, two primibrachials on the $\mathrm{D}$ and $\mathrm{E}$ rays (the only rays preserving arm plates), and subcuneate brachials. The Nada specimen (Fig. 2.12, 2.13) was compared to the holotype of D. scalaris, MCZ 103749. Those cup and arm characters that are preserved are identical between the two specimens, thus leaving little doubt of the identification.

Subclass FLEXIBILIA von Zittel, 1895

Order TAXOCRINIDA Springer, 1913

Superfamily TAXOCRINOIDEA Angelin, 1878

Family TAXOCRINIDAE Angelin, 1878

Genus TAXOCRINUs Phillips, 1843

Type species.-Cyathocrinus? macrodactylus Phillips, 1841, by subsequent designation of Worthen in Meek and Worthen (1866).

TAXOCRINUS spp.

Taxocrinus sp. LANE AND DUBAR, 1983, p. 121, fig. 3h.

Material examined.-USNM 312184 from locality 1 and OSU 51538, OSU 51539, and OSU 51542 from locality 5.

Occurrence.-Nada Member of the Borden Formation.

Discussion.-Four incomplete or crushed flexibles are known from the Nada Member that may represent two or three species. These are all provisionally assigned to Taxocrinus spp., but at least one may not belong in this genus.

USNM 312184 and OSU 51538 are small specimens and presumably the same species. The former is a set of arms, and the latter is a badly crushed partial crown. This may be T. juvenis (Hall, 1861a), but the Nada specimens have an expanding rather than narrow crown.

OSU 51539 is a partial set of arms of a medium-sized specimen. These are more robust with wider brachials than the specimens discussed above. It is probable that this specimen belongs to Taxocrinus but to a separate species than USNM 312184 and OSU 51538.

OSU 51542 is little more than a very large set of arms (crown diameter $9 \mathrm{~cm}$ ). It is probable that this specimen does not belong to Taxocrinus; however, it is certainly a third flexible species.

Subclass DisParida Moore and Laudon, 1943

Superfamily BELEMNOCRINOIDEA Miller, 1883

Family SYNBATHOCRINIDAE Miller, 1889

Genus SYNBATHOCRINUS Phillips, 1836

Type species.-Synbathocrinus conicus Phillips, 1836, by monotypy.

FIGURE 2-Nada Member and Burlington Limestone crinoids. 1, 2, Meniscocrinus sp., USNM 50476, $\times 3.0$ specimens from the Nada Member; 1 , basal view coated with ammonium chloride, 2, basal view photographed wetted in water. 3-5, Pellecrinus obuncus (White, 1862), $\times 2.5$; 3, OSU 51537, isolated radial plate from the Nada Member; 4, 5, holotype, MCZ 504512, specimen from the "lower part" (now BPA I) Burlington Limestone, 4, basal view, 5, lateral view. 6-9, Holcocrinus spinobrachiatus (Hall, 1861a); 6, holotype, USNM S 2860, ×1.0, partially disarticulated crown, specimen from the "upper part" Burlington Limestone; 7, 8, USNM S 2861, ×2.0, specimen from the "upper part" Burlington Limestone, 7, E-ray lateral view, 8, D-ray lateral view; 9, OSU 50390, ×2.0, CD-interray view, specimen from Nada Member. 10, 11, Blothrocrinus swallovi (Meek and Worthen, 1860), OSU 50391, ×1.0 from the Nada Member; 10, anterior view, 11, posterior view. 12, 13, Decadocrinus scalaris (Meek and Worthen, 1870), OSU 51536, $\times 2.0$ from the Nada Member; 12, anterior view, 13, posterior view. 
SYNBATHOCRINUS DENTATUS Owen and Shumard, 1852

Synbathocrinus dentatus Owen AND ShUMARD, 1852, p. 93, pl. 11, fig.

7; Bassler ANd MoOdey, 1943, p. 695; Webster, 2003, p. 1714. Synbathocrinus sp. LANE AND DUBAR, 1983, p. 220, fig. $3 \mathrm{f}$.

Diagnosis.-Aboral cup medium-sized for genus, medium cone-shaped, sides straight in lateral view; basal circlet high; radial plates gently convex; radial: radial sutures flush to slightly depressed; brachials aborally convex in large specimens, subangular to convex in smaller specimens.

Material examined.-USNM 312180 (locality 1), OSU 50384 (locality 1), OSU 50385 (locality 1), OSU 51584 (locality 7), and OSU 51585 (locality 2).

Occurrence.-Bassler and Moodey (1943) reported S. dentatus from the "upper part" of the Burlington Limestone at Burlington, Iowa, Gahn (2002) reported it from BPA II and III, and it is in the Nada Member of the Borden Formation.

Discussion.- - Lane and DuBar (1983) had a single specimen of Synbathocrinus, which they left in open nomenclature. Four additional specimens are now available. This collection has large and small specimens. The smaller specimens have convex to subangular (both enhanced by compaction) brachials aborally. However, the characters of the aboral cup are consistent. S. dentatus is distinguished from S. blairi Miller, 1891b, S. brevis Meek and Worthen, 1869, S. swallovi Hall, 1858, and S. wortheni Hall, 1858 by having high basals and from $S$. wachsmuthi Meek and Worthen, 1869 by having convex to subangular dorsal brachials and a large anal X.

Superfamily CALCEOCRINOIDEA Meek and Worthen, 1869

Family CALCEOCRINIDAE Meek and Worthen, 1865 Genus HALYSIOCRINUS Ulrich, 1886

Type species.-Cheirocrinus dactylus Hall, 1860, by original designation.

\section{HALYSIOCRINUS DACTYLUS (Hall, 1860)}

Cheirocrinus dactylus Hall, 1860, p. 123, figs. 1, 20.

Halysiocrinus dactylus (HALL, 1860). SPRINGER, 1926, p. 95, pl. 30, figs.

1-3a; BASSLER AND MoOdey, 1943, p. 500; Webster, 2003, p. 1029.

Calceocrinus? wachsmuthi MEEK AND WORTHEN, 1869, p. 74.

Diagnosis.-Aboral cup adanally-abanally compressed; smooth to granulose plates; nodes absent on $\mathrm{A}$ and $\mathrm{D}$ radials; node absent on E superradial, three to five axil arms, no axillaries in main axil series after first brachial; E arm brachials not nodose; primibrachial 6-9 axillary on $\mathrm{E}$ arm, branching of the $\mathrm{E}$ arm once or twice, atomous.

Material examined.-OSU 50386 (locality 7) an aboral cup with proximal arms.

Occurrence.-Bassler and Moodey (1943) reported H. dactylus from the "upper part" of the Burlington Limestone, Burlington, Iowa, Gahn (2002) reported it from BPA I to BPA III, and it is in the Nada Member of the Borden Formation.

Discussion.-Although arm branching cannot be assessed, other characters indicate that this species should be assigned to Halysiocrinus dactylus. $H$. dactylus is most similar to $H$. tunicatus Hall, 1860 (see Ausich et al., 1997) but differs by having fewer axil arms, convex E-arm brachials, isotomous divisions in $\mathrm{E}$ arm, and nonswollen axillaries in lateral arms. Note that Brower (1987) is followed here with Halysiocrinus wachsmuthi (Meek and Worthern, 1869), considered a junior synonym of $H$. dactylus.

\section{ACKNOWLEDGMENTS}

This study was begun as part of dissertation research (KL) in the Department of Geological Sciences, The Ohio State University. Support from The Ohio State University is gratefully acknowledged. We thank B. Heath and M. Hill for help in typing,
C. E. Mason and S. A. Judge for help in the field, D. Gnidovec (Orton Museum of Geology, The Ohio State University) and J. Thompson (U.S. National Museum) for access to collections, and R. H. Mapes (Ohio University) for donating specimens. F. J. Gahn and D. L. Meyer made important improvements to the final manuscript. This research was partially supported by the National Science Foundation (EAR-02059068 and EAR-0206307).

\section{REFERENCES}

AngELIN, N. P. 1878. Iconographia crinoideorum in stratis Sueciae Siluricus fossilium. Samson and Wallin, Holmiae, 62 p.

AusicH, W. I. 1997. Regional encrinites: a vanished lithofacies, p. 509519. In C. E. Brett and G. C. Baird (eds.), Paleontological Events Stratigraphic, Ecological, and Evolutionary Implications. Columbia University Press, New York.

Ausich, W. I. 1998. Early phylogeny and subclass division of the Crinoidea (Phylum Echinodermata). Journal of Paleontology, 72:499-510.

Ausich, W. I., AND T. W. KAMMER. 1990. Systematics and phylogeny of the late Osagean and Meramecian crinoids Platycrinites and Eucladocrinus from the Mississippian stratotype region. Journal of Paleontology, 64:759-778.

AUSICH, W. I., AND N. G. LANE. 1980. Platform communities and rocks of the Borden Siltstone delta (Mississippian) along the south shore of Monroe Reservoir, Monroe County, Indiana, p. 36-67. In R. H. Shaver (ed.), Field Trips 1980 from the Indiana University Campus, Bloomington. Indiana University, Bloomington.

Ausich, W. I., AND N. G. LANE. 1982. Crinoids from the Edwardsville Formation (Lower Mississippian) of southern Indiana. Journal of Paleontology, 56:1343-1461.

Ausich, W. I., AND D. L. MeYer. 1990. Origin and composition of carbonate buildups and associated facies in the Fort Payne Formation (Lower Mississippian, south-central Kentucky): an integrated sedimentologic and paleoecologic analysis. Geological Society of America Bulletin, 102:129-146.

Ausich, W. I., And G. D. Sevastopulo. 1994. Taphonomy of Lower Carboniferous crinoids from the Hook Head Formation, Ireland. Lethaia, 27:245-256.

Ausich, W. I., And G. D. Sevastopulo. 2001. The Tournaisian Crinoids from Hook Head, County Wexford, Ireland. Palaeontolographical Association, London, 617, 136 p.

Ausich, W. I., T. W. Kammer, And T. K. Baumiller. 1994. Demise of the Middle Paleozoic crinoid fauna: a single extinction event or a rapid faunal turnover? Paleobiology, 20:345-361.

Ausich, W. I., T. W. Kammer, AND N. G. LANE. 1979. Fossil communities of the Borden (Mississippian) delta in Indiana and northern Kentucky. Journal of Paleontology, 53:1182-1196.

Ausich, W. I., T. W. Kammer, AND D. L. Meyer. 1997. Middle Mississippian disparid crinoids from the midcontinental United States. Journal of Paleontology, 71:131-148.

Austin, T. SR., AND T. AUstin JR. 1842. Proposed arrangement of the Echinodermata, particularly as regards the Crinoidea, and a subdivision of the class Adelostella (Echinidae). Annals and Magazine of Natural History, series 1, 11:195-207.

Bassler, R. S. 1938. Pelmatozoan Palaeozoica, p. 1-194. In W. Quenstedt (ed.), Fossilium Catalogus, I: Animalia. W. Junk, s'Gravenhage.

Bassler, R. S., AND M. W. Moodey. 1943. Bibliographic and faunal index of Paleozoic pelmatozoan echinoderms. Geological Society of America Special Paper, 45, 734 p.

BAtHER, F. A. 1890. British fossil crinoids II: the classification of the Inadunata Fistulata. Annals and Magazine of Natural History, series 6, 5:373-388, 485-486.

BAther, F. A. 1899. A phylogenetic classification of the Pelmatozoa. British Association for the Advancement of Science Report, 1898:916923.

BAtURIN, G. N. 1982. Phosphorites on the sea floor: origin, composition, and distribution. Developments in Sedimentology, Number 33, 343 p.

BAumiller, T. K. 1994. Patterns of dominance and extinction in the record of Paleozoic crinoids, p. 193-198. In B. David, A. Guille, J. P. Féral, and M. Roux (eds.), Echinoderms Through Time. Balkema Press, Rotterdam.

BroAdHEAD, T. W. 1981. Carboniferous camerate crinoid subfamily, Dichocrininae: Palaeontographica, Abt. A, 176:81-157. 
BRONN, H. G. 1849. Index palaeontologicus, unter Mitwirkung der Herren Prof. H. R. Göppert und H. von Meyer. Handbuch einer Geschichte der Natur, Nomenclator paleontologicus, 5(2):776-1381.

Brower, J. C. 1965. The genus Steganocrinus. Journal of Paleontology, 39:773-793.

Brower, J. C. 1967. The actinocrinitid genera Abactinocrinus, Aacocrinus, and Blairocrinus. Journal of Paleontology, 41:675-705.

BROWER, J. C. 1987. The relations between allometry, phylogeny, and functional morphology in some calceocrinid crinoids. Journal of $\mathrm{Pa}-$ leontology, 61:999-1032.

Casseday, S. A., AND S. S. Lyon. 1862. Description of two new genera and eight new species of fossil Crinoidea from the rocks of Indiana and Kentucky. American Academy of Arts and Sciences Proceedings, 5:16-31.

Chaplin, J. R. 1980. Stratigraphy, trace fossil associations, and depositional environments in the Borden Formation (Mississippian), northeastern Kentucky. Annual Field Conference Guidebook, Geological Society of Kentucky, 1980. Kentucky Geological Survey, Lexington, 114 p.

Collinson, C., C. B. ReXroAd, And T. L. Thompson. 1971. Conodont zonation of the North American Mississippian. Geological Society of America Memoir, 127, p. 353-394.

DE KonincK, L. G., AND H. S. LEHON. 1854. Recherches sur les crinoïdes du terrain carbonifère. Royal Academy Belgique Memoir, 28, 217 p.

Ehlers, G. M., AND R. V. Kesling. 1963. Two new crinoids from Lower Mississippian rocks in southeastern Kentucky. Journal of Paleontology, 37:1028-1041.

Ettensohn, F. R., C. L. Rice, G. R. Dever JR., and D. R. Chesnut. 1984. Slade and Paragon formations - new stratigraphic nomenclature for Mississippian rocks along the Cumberland Escarpment in Kentucky. U.S. Geological Survey Bulletin, 1605, 37 p.

GAHN, F. J. 2002. Crinoid and blastoid biozonation and biodiversity in the Early Mississippian (Osagean) Burlington Limestone. Iowa Department of Natural Resources Geological Survey Guidebook, 23:5374.

GaHn, F. J., AND T. W. KAMmer. 2002. The cladid crinoid Barycrinus from the Burlington Limestone (Early Osagean) and the phylogenetics of Mississippian botryocrinids. Journal of Paleontology, 76:123-133.

HALL, J. 1858. Report on the Geological Survey of Iowa, embracing the results of investigations made during portions of the years 1855, 1856, 1857. Geological Survey of Iowa, 1, Pt. 2, Paleontology, 724 p.

HALL, J. 1859. Contributions to the palaeontology of Iowa, being descriptions of new species of Crinoidea and other fossils. Geological Report of Iowa, 1, Pt. 2, supplement, 1-92 p.

HALL, J. 1860. Observations upon a new genus of Crinoidea: Cheirocrinus, p. 121-124. In Contributions to Palaeontology, 1858 and 1859, Thirteenth Annual Report of the Regents of the University of the State of New York, on the Condition of the State Cabinet of Natural History, and the Historical Antiquarian Collection Annexed thereto, Appendix F, State of New York Senate Document 89.

HaLl, J. 1861a. Descriptions of new species of Crinoidea from the Carboniferous rocks of the Mississippi Valley. Boston Society of Natural History Journal, 7:261-328.

HALL, J. 1861b. Descriptions of new species of Crinoidea; from investigations of the Iowa Geological Survey. Preliminary notice. C. van Benthuyen, Albany, New York, 18 p.

HARRIS, L. C., AND B. M. Whiting. 2000. Sequence-stratigraphic significance of Miocene to Pliocene glauconite-rich layers, on- and offshore of the US Mid-Atlantic margin. Sedimentary Geology, 134:129147.

JAEKel, O. 1918. Phylogenie und system der Pelmatozoen. Paläeontologische Zeitschrift, 3:383-385.

Kammer, T. W. 1984. Crinoids from the New Providence Shale Member of the Borden Formation (Mississippian) in Kentucky and Indiana. Journal of Paleontology, 58:115-130.

Kammer, T. W. 2001. Phenotypic bradytely in the Costalocrinus-Barycrinus lineage of Paleozoic cladid crinoids. Journal of Paleontology, 75:383-389.

Kammer, T. W., AND W. I. Ausich. 1987. Aerosol suspension feeding and current velocities: distributional controls for late Osagean crinoids. Paleobiology, 13:379-395.

Kammer, T. W., AND W. I. Ausich. 1993. Advanced cladid crinoids from the Middle Mississippian of the east-central United States: intermediate-grade calyces. Journal of Paleontology, 67:614-639.
Kammer, T. W., AND W. I. Ausich. 1996. Primitive cladid crinoids from Upper Osagean-Lower Meramecian (Mississippian) rocks of east-central United States. Journal of Paleontology, 70:835-866.

Kammer, T. W., and F. J. Gahn. 2003. Primitive cladid crinoids from the early Osagean Burlington Limestone and the phylogenetics of Mississippian species of Cyathocrinites. Journal of Paleontology, 77:121138

Kammer, T. W., T. K. Baumiller, And W. I. Ausich. 1997. Species longevity as a function of niche breadth: evidence from fossil crinoids. Geology, 25:219-222.

Kammer, T. W., T. K. BaumiLler, AND W. I. Ausich. 1998. Evolutionary significance of differential species longevity in Osagean-Meramecian (Mississippian) crinoid clades. Paleobiology, 24:155-176.

Khetani, A. B., AND J. F. READ. 2002. Sequence development of a mixed carbonate-siliciclastic high-relief ramp, Mississippian, Kentucky, U.S.A. Journal of Sedimentary Research, 72:657-672.

KIDWELL, S. M. 1989. Stratigraphic condensation of marine transgressive records: origin of major shell deposits in the Miocene of Maryland. Journal of Geology, 97:1-29.

KIRK, E. 1929. The fossil crinoid genus Vasocrinus Lyon. Proceedings of the U.S. National Museum, 74:1-16.

KIRK, E. 1940. Seven new genera of Carboniferous Crinoidea Inadunata. Journal of the Washington Academy of Science, 30:321-334.

KIRK, E. 1943. A revision of the genus Steganocrinus. Journal of the Washington Academy of Science, 33:259-265.

KIRK, E. 1944. Cytidocrinus, a new name for Cyrtocrinus Kirk. Journal of the Washington Academy of Science, 34:85.

KIRK, E. 1945. Holcocrinus, a new inadunate crinoid genus from the Lower Mississippian. American Journal of Science, 234:517-521.

LANE, H. R., AND P. L. BRENCKLE. 2001. Type Mississippian subdivisions and biostratigraphic succession, p. 83-107. In P. H. Heckel (ed.), Stratigraphy and Biostratigraphy of the Mississippian Subsystem (Carboniferous System) in its type region, the Mississippi River Valley of Illinois, Missouri, and Iowa. IUGS Subcommission on Carboniferous Stratigraphy. Department of Geosciences, University of Iowa, Iowa City.

LANE, N. G. 1958. The monobathrid camerate crinoid family: Batocrinidae. Ph.D. dissertation, University of Kansas, Lawrence, 259 p.

LANE, N. G. 1971. Crinoids and reefs. Proceedings of the North American Paleontological Convention, Part J:1430-1443.

LANE, N. G. 1973. Paleontology and paleoecology of the Crawfordsville fossil site (Upper Osagean: Indiana). California University Publications in the Geological Sciences, Number 99, $141 \mathrm{p}$.

LANE, N. G., AND J. R. DuBAR. 1983. Progradation of the Borden delta: new evidence from crinoids. Journal of Paleontology, 57:112-123.

LYON, S. S., AND S. A. CASSEDAY. 1859. A synonymic list of the Echinodermata of the Palaeozoic rocks of North America. American Academy of Arts and Sciences Proceedings, 4:282-304.

McChesney, J. H. 1860. Description of fossils from the Palaeozoic rocks of western states, with illustration. Transactions of the Chicago Academy of Sciences, 1:1-57.

McInTosh, G. 1984. Devonian cladid inadunate crinoids: Family Botryocrinidae Bather, 1899. Journal of Paleontology, 58:1260-1281.

MeeK, F. B. 1872. Preliminary list of the fossils collected by Dr. Hayden's exploring expedition of 1871 , in Utah and Wyoming Territories, with descriptions of new fossils, p. 373-377. In F. V. Hayden (ed.), Preliminary Report of the United States Geological Survey of Montana and Portions of Adjacent Territories, Preliminary Report (fifth annual), 1871.

Meek, F. B., AND A. H. Worthen. 1860. Descriptions of new species of Crinoidea and Echinoidea from the Carboniferous rocks of Illinois, and other western states. Philadelphia Academy of Sciences Proceedings, series 2, 4:379-397.

MeEk, F. B., AND A. H. Worthen. 1861. Descriptions of new Paleozoic fossils from Illinois and Iowa. Academy of Natural Sciences of Philadelphia Proceedings, series 1, 13:128-146.

MeeK, F. B., AND A. H. Worthen. 1865. Description of new species of Crinoidea from the Paleozoic rocks of Illinois and some of the adjoining states. Academy of Natural Sciences of Philadelphia Proceedings, $17: 143-155$

Meek, F. B., AND A. H. WoRTHEN. 1866. Descriptions of invertebrates from the Carboniferous System. Illinois Geological Survey, 2:143-411. MeEK, F. B., AND A. H. Worthen. 1868. Remarks on some types of 
Carboniferous Crinoidea with descriptions of new genera and species of the same, and of one echinoid. Academy of Natural Sciences of Philadelphia Proceedings, 20:335-359.

Meek, F. B., AND A. H. Worthen. 1869. Descriptions of new Crinoidea and Echinoidea from the Carbonifeous rocks of the western states with a note on the genus Onycaster. Academy of Natural Sciences of Philadelphia Proceedings, 21:67-83.

MeeK, F. B., AND A. H. Worthen. 1870. Descriptions of new Carboniferous fossils from the western states. Academy of Natural Sciences of Philadelphia Proceedings, 22:137-172.

Meek, F. B., And A. H. Worthen. 1873. Paleontology. Descriptions of invertebrates from the Carboniferous System. Illinois Geological Survey, 5(2):323-619.

Meyer, D. L., AND W. I. Ausich. 1997. Morphologic variation within and among populations of the camerate crinoid Agaricocrinus (Lower Mississippian, Kentucky and Tennessee) breaking the spell of the mushroom. Journal of Paleontology, 71:896-917.

Meyer, D. L., W. I. Ausich, AND R. E. Terry. 1990. Comparative taphonomy of echinoderms in carbonate facies: Fort Payne Formation (Lower Mississippian) of Kentucky and Tennessee. Palaios, 4:533-552.

MiLlER, J. S. 1821. A Natural History of the Crinoidea or Lily-shaped Animals, With Observation on the Genera Asteria, Euryale, Comatula, and Marsupites. Bryan \& Co., Bristol, 150 p.

Miller, S. A. 1883. The American Palaeozoic Fossils: a catalogue of the genera and species, with names of authors, dates, places of publications, groups of books in which found, and the etymology and signification of the words, and an introduction devoted to the stratigraphical geology of Palaeozoic rocks, Echinodermata (second edition). Published by the author, Cincinnati, Ohio, $334 \mathrm{p}$.

MiLLER, S. A. 1889. North American Geology and Paleontology. Western Methodist Book Concern, Cincinnati, Ohio, 664 p.

Miller, S. A. 1891a. Palaeontology: Advance sheets. Indiana Department of Geology and Natural Resources, $17^{\text {th }}$ Annual Report, $103 \mathrm{p}$.

Miller, S. A., 1891b. A description of some Lower Carboniferous crinoids. Geological Survey of Missouri Bulletin, 4:1-40.

Miller, S. A. 1892. North American Geology and Paleontology, first appendix. Western Methodist Book Concern, Cincinnati, Ohio, p. 665718.

Miller, S. A., AND W. F. E. Gurley. 1897. New species of crinoids, cephalopods, and other Palaeozoic fossils. Illinois State Mueum of Natural History Bulletin, 12, $69 \mathrm{p}$.

Moore, R. C. 1952. Crinoids, p. 604-652. In R. C. Moore, C. G. Lalicker, and A. G. Fischer (eds.), Invertebrate Fossils. McGraw-Hill, New York.

MoORE, R. C., AND L. R. LAUdON. 1943. Evolution and classification of Paleozoic crinoids. Geological Society of America Special Paper, 46, $153 \mathrm{p}$.

MoOre, R. C., AND C. Teichert (EDS.). 1978. Treatise on Invertebrate Paleontology, Part T, Echinodermata 2. Geological Society of America and The University of Kansas Press, Lawrence, 1027 p.

MüNSTER, G. G. ZU. 1839. Beschreibung einiger neuer Crinoideen aus der Übergangsformation. Beiträge zur Petrefaktenkunde, 1:1-124.

Owen, D. D., AND B. F. Shumard. 1850. Descriptions of fifteen new species of Crinoidea from the Subcarboniferous limestone of Iowa. Academy of Natural Sciences of Philadelphia, series 2, 2:57-70.

Owen, D. D., AND B. F. Shumard. 1852. Descriptions of seven new species of Crinoidea from the Subcarboniferous limestone of Iowa and Illinois. Journal of the Philadelphia Academy of Sciences, series 2, 2: 89-94.

PhILLIPS, J. 1836. Illustration of the Geology of Yorkshire, or a description of the strata and organic remains, Pt. 2, The Mountain Limestone Districts. John Murray, London, 253 p.

PhILLIPS, J. 1841. Figures and Descriptions of the Palaeozoic Fossils of Cornwall, Devon, and West Somerset; observed in the course of the ordinance geological survey of that district. Longmans, Brown, Green, and Longmans, London, $232 \mathrm{p}$.

PhILliPs, J. 1843. Taxocrinus, p. 59. In J. Morris (ed.), A Catalogue of British Fossils. Comprising all the genera and species hitherto described; with reference to their geological distribution and to the localities in which they have been found (first edition). John Van Voorst, London.

Porrenga, D. H. 1967. Glauconite and chamosite as depth indicators in the marine environment, p. 495-502. In A. Hallam (ed.), Depth Indicators in Marine Sedimentary Rocks. Marine Sedimentary Geology, Special Issue 5, no. 5/6.

Posamentier, H. W., AND G. P. Allen. 1999. Siliciclastic Sequence Stratigraphy-Concepts and Applications. SEPM Concepts in Sedimentology and Paleontology, No. 7, 210 p.

Richardson, J. G. 2003. Sedimentology, sequence stratigraphy, and miospore zonation of the Lower Mississippian (Osage) Borden Formation in Kentucky and adjacent states. Unpublished Ph.D. dissertation, Ohio State University, Columbus.

Roemer, F. A. 1855. Erste Periode, Kohlen-Gebirge, 788 p. In H. G. Bronn (ed.), Lethaea Geognostica (third edition), 2. E. Schweizerbart, Stuttgart.

Roeser, E. W. 1986. A Lower Mississippian (Kinderhookian-Osagian) crinoid fauna from the Cuyahoga Formation of northeastern Ohio. Unpublished M.S. thesis, University of Cincinnati, $322 \mathrm{p}$.

Rowley, R. R. 1900. New species of crinoids, blastoids, and cystoids from Missouri. American Geologist, 25:65-75.

Rowley, R. R., AND S. J. HARE. 1891. Description of some new species of crinoids and blastoids from the Sub-carboniferous rocks of Pike and Marion Counties, Mo., and Scott County, Ia. Kansas City Scientist, 5(8):113-118.

Sable, E. G., AND G. R. Dever JR. 1990. Mississippian rocks in Kentucky. U.S. Geological Survey Professional Paper, 1503, 125 p.

Schultze, L. 1867. Monographie der Echinodermen des Eifler Kalkes. Kaiserlich Akademie der Wissenschaften Mathematisch-Naturwissenschaftlichen Classe, Wien, 26:113-230.

SHUMARD, B. F. 1855. Description of new species of organic remains. Missouri Geological Survey, 2:185-208.

Shumard, B. F. 1858. Description of new fossil Crinoidea from the Palaeozoic rocks of the western and southern portions of the United States. Transactions of the St. Louis Academy of Sciences (1857), 1: $71-80$.

SpRINGER, F. 1913. Crinoidea, p. 173-243. In K. A. von Zittel (ed.), Textbook of Paleontology (second edition). Macmillan and Company, London, England.

SPRINGER, F. 1926. Unusual forms of fossil crinoids. U.S. National Museum Proceedings, 67, Article 9, $137 \mathrm{p}$.

Ubaghs, G. 1953. Classe des Crinoïdes, p. 658-773. In J. Piveteau (ed.), Traité de paléontologie, 3. Masson and Cie, Paris.

Ubaghs, G. 1978a. Skeletal morphology of fossil crinoids, p. 58-216. In R. C. Moore and C. Teichert (eds.), Treatise on Invertebrate Paleontology, Pt. T, Crinoidea. Geological Society of America and University of Kansas Press, Lawrence.

Ubaghs, G. 1978b. Suborder Compsocrinina Ubaghs, new suborder, p. 440-452. In R. C. Moore and C. Teichert (eds.), Treatise on Invertebrate Paleontology, Pt. T, Echinodermata 2. Geological Society of America and University of Kansas Press, Lawrence.

UlRICH, E. O. 1886. Remarks upon the names Cheirocrinus and Calceocrinus, with descriptions of three new generic terms and one new species. Minnesota Geology and Natural History Survey Annual Report, $14: 104-113$

VAN SANT, J. F., AND N. G. LANE. 1964. Crawfordsville (Indiana) crinoid studies. The University of Kansas Paleontological Contributions, Article 7, University of Kansas, Lawrence, 136 p.

von ZitTel, K. A. von. 1895. Grundzüge der Palaeontologie (Palaeozoologie) (first edition). R. Oldenbourg, München, $971 \mathrm{p}$.

WaCHSMUth, C., AND F. SPRINGER. 1878. Transitional forms in crinoids, and description of five new species. Proceedings of the Academy of Natural Sciences of Philadelphia, 224-266.

Wachsmuth, C., AND F. Springer. 1880. Revision of the Palaeocrinoidea, Pt. I, The families Ichthyocrinidae and Cyathocrinidae. Proceedings of the Academy of Natural Sciences of Philadelphia, 226-378.

WachSMUth, C., AND F. SPRINGer. 1881. Revision of the Palaeocrinoidea, Pt. II, Family Sphaeroidocrinidae, with the sub-families Platycrinidae, Rhodocrinidae, and Actinocrinidae. Proceedings of the Academy of Natural Sciences of Philadelphia, p. 177-411.

Wachsmuth, C., AND F. SPRINGER. 1885. Revision of the Palaeocrinoidea, Pt. 3, section 1. Proceedings of the Academy of Natural Sciences of Philadelphia, p. 223-364.

Wachsmuth, C., AND F. SpRINGer. 1886. Revision of the Paleocrinoidea, Pt. 3, section 2. Proceeding of the Academy of Natural Sciences of Philadelphia, p. 140-302. 
Wachsmuth, C., AND F. SpRinger. 1890. New species of crinoids and blastoids from the Kinderhook Group of the Lower Carboniferous rocks at LeGrand, Iowa, and a new genus from the Niagaran Group of Western Tennessee. Illinois Geological Survey, 8:155-208.

Wachsmuth, C., AND F. SPRINGer. 1897. The North American Crinoidea Camerata. Harvard College Museum of Comparative Zoology Memoir, 20, 897 p.

Webster, G. D. 2003. Bibliography and index of Paleozoic crinoids 1981-1985. Geological Society of America Special Paper, 363 (CD).

Weir, G. W., K. Y. LeE, And P. E. CAssity. 1971. Geologic map of the Bighill quadrangle, east-central Kentucky. U.S. Geological Survey Geologic Quadrangle Map, GQ-900.

White, C. A. 1862. Description of new species of fossils from the Devonian and Carboniferous rocks of the Mississippi Valley. Boston Society of Natural History Journal, 9:8-33.

WhITE, C. A. 1863. Observations on the summit structure of Pentremites, the structure and arrangement of certain parts of crinoids, and descriptions of new species from the Carboniferous rocks of Burlington, Iowa. Boston Society Natural History Journal, 7:481-506.

WhitFieLD, R. P. 1881. Description of a new species of crinoid from the Burlington Limestone, at Burlington, Iowa. American Museum of Natural History Bulletin, 1:7-11.

Work, D. M., AND C. E. MAson. 2003. Mississippian (Middle Osagean) ammonoids from the Nada Member of the Borden Formation, Kentucky. Journal of Paleontology, 77:593-596.

ACCEPTED 10 APRIL 2004
APPENDIX A-LOCALITIES OF NADA MEMBER CRINOIDS

Locality 1-Milepost 149.7. Road cut on southern side of Interstate 64 at milepost 149.7, 12 miles east of Morehead (exit 137), Soldier 7.5 min quadrangle, Rowan County, Kentucky; GPS: $38^{\circ} 17.481^{\prime} \mathrm{N} 83^{\circ} 19.081^{\prime} \mathrm{W}$.

Locality 2-Milepost 146.2. Roadcut on northern side of Interstate 64 at milepost 146.2, 9 miles east of Morehead (exit 137), Cranston 7.5 min. quadrangle, Rowan County, Kentucky; GPS: $38^{\circ} 16.569^{\prime} \mathrm{N} 83^{\circ} 22.533^{\prime} \mathrm{W}$

Locality 3-Leatherwood. Roadcut on northern side of Leatherwood Road, 10.7 miles east of Kentucky Highway 36, Salt Lick 7.5 min. quadrangle, Menifee County, Kentucky; GPS: $38^{\circ} 02.215^{\prime} \mathrm{N} 83^{\circ} 31.503^{\prime} \mathrm{W}$.

Locality 4-Hill Top Church. Roadcut on both sides of Kentucky Highway 36, 3.0 miles north of the junction of Kentucky Highway 36 and U.S. Highway 460 in Frenchburg, Scranton 7.5 min. quadrangle, Menifee County, Kentucky; GPS: $37^{\circ} 59.178^{\prime} \mathrm{N} 83^{\circ} 37.246^{\prime} \mathrm{W}$.

Locality 5-Frenchburg West. Roadcut on southern side of U.S. Highway 460, 2.8 miles west of the junction of Kentucky Highway 36 and U.S. Highway 460 in Frenchburg, Frenchburg 7.5 min. quadrangle, Menifee County, Kentucky; GPS: $37^{\circ} 57.574^{\prime} \mathrm{N} 83^{\circ} 40.240^{\prime} \mathrm{W}$.

Locality 6-Frenchburg East A. Roadcut on northeastern side of U.S Highway 460, 0.5 miles east of the junction of Kentucky Highway 36 and U.S. Highway 460 in Frenchburg, Scranton 7.5 min. quadrangle, Menifee County, Kentucky; GPS: $37^{\circ} 56.697^{\prime} \mathrm{N} 83^{\circ} 37.295^{\prime} \mathrm{W}$.

Locality 7-Highway 460 West. Roadcut on both sides of U.S. Highway 460, 3.8 miles west of the junction of Kentucky Highway 36 and U.S Highway 460 in Frenchburg, Frenchburg 7.5 min. quadrangle, Menifee County, Kentucky; GPS: $37^{\circ} 57.421^{\prime} \mathrm{N} 83^{\circ} 41.188^{\prime} \mathrm{W}$.

Locality 8-Frenchburg East B. Roadcut on southestern side of U.S. Highway 460, 0.6 miles east of the junction of Kentucky Highway 36 and U.S. Highway 460 in Frenchburg, Scranton $7.5 \mathrm{~min}$. quadrangle, Menifee County, Kentucky; GPS: $37^{\circ} 56.624^{\prime} \mathrm{N} 83^{\circ} 37.227^{\prime} \mathrm{W}$. 